Check for updates

Cite this: RSC Adv., 2019, 9, 10034

Received 23rd January 2019

Accepted 11th March 2019

DOI: 10.1039/c9ra00582j

rsc.li/rsc-advances

\section{New chemical mechanism explaining the breakdown of protective oxides on high temperature steels in biomass combustion and gasification plants $\uparrow$}

\author{
Tom Blomberg, (D)* Tripurari Tripathi and Maarit Karppinen (D)
}

\begin{abstract}
Biomass is considered a replacement fuel over fossil fuels to mitigate climate change. The switch to biomass in the combustors changes the inorganic chemistry of the flue gases and leads to more severe corrosion of the construction materials of the combustors. The integrity of most high temperature steels relies on the formation of a protective $\mathrm{Cr}_{2} \mathrm{O}_{3}$ layer on the steel surface at a high temperature environment. The ash compound found on the heavily corroded steel in biomass combustion and gasification plants is $\mathrm{KCl}$, but the mechanism, which triggers the breakdown of the protective $\mathrm{Cr}_{2} \mathrm{O}_{3}$ layer under the $\mathrm{KCl}$ salt is not known. We studied the chemical reactions involved with furnace exposure of $\mathrm{KCl}$ and $\mathrm{KOH}$ with $\mathrm{Cr}_{2} \mathrm{O}_{3}$ and identified the formed reaction products with XRD analysis. The amount of reaction products was analyzed from the leachates of the salt-oxide mixtures by UV/VIS spectroscopy. We also used thermodynamic Gibbs energy minimization calculations to evaluate the evolution of reactions as a function of temperature. The results suggests that the reaction of $\mathrm{KCl}$ with $\mathrm{Cr}_{2} \mathrm{O}_{3}$ involves a $\mathrm{KOH}$ reaction intermediate that forms before $\mathrm{K}_{2} \mathrm{CrO}_{4}$ is formed. The amount of reacted potassium as a function of temperature follows the trend of $\mathrm{KCl}$ decomposition to $\mathrm{KOH}$ and $\mathrm{HCl}(\mathrm{g})$ as predicted by thermodynamics calculations. Therefore, we argue that the suggested overall reaction of $\mathrm{KCl}$ with $\mathrm{Cr}_{2} \mathrm{O}_{3}$ as found in the corrosion literature: $4 \mathrm{KCl}+\mathrm{Cr}_{2} \mathrm{O}_{3}+1 \frac{1}{2} \mathrm{O}_{2}(\mathrm{~g})+2 \mathrm{H}_{2} \mathrm{O}(\mathrm{g}) \Rightarrow 2 \mathrm{~K}_{2} \mathrm{CrO}_{4}+4 \mathrm{HCl}(\mathrm{g})$, starting with the initiation step: $\mathrm{KCl}+\mathrm{H}_{2} \mathrm{O}(\mathrm{g})$ $\Rightarrow \mathrm{KOH}+\mathrm{HCl}(\mathrm{g})$ and then the formed $\mathrm{KOH}$ reacts with $\mathrm{Cr}_{2} \mathrm{O}_{3}$ to form $\mathrm{K}_{2} \mathrm{CrO}_{4}$. This explains the initial breakdown of the protective $\mathrm{Cr}_{2} \mathrm{O}_{3}$ under $\mathrm{KCl}$ salt in water containing high temperature atmospheres. The result is essential for the development of new alloys for biomass fired combustors.
\end{abstract}

\section{Introduction}

Burning coal is responsible for approximately $25 \%$ of anthropogenic $\mathrm{CO}_{2}$ emissions. The largest use of coal as a fuel is in electricity and heat production, which accounts for about $16 \%$ of the total $\mathrm{CO}_{2}$ emissions. ${ }^{1}$ Replacing coal with sustainable biomass as the fuel in power boilers would lead to substantial reductions in the net $\mathrm{CO}_{2}$ emission. Also, $\mathrm{SO}_{2}$ emissions would be diminished due to the generally much lower sulphur content of biomass based fuels compared to coal. However, biomass combustion leads to more severe fouling and corrosion issues of the heat transfer surfaces in boilers. ${ }^{2-5}$ One way to minimize these

Aalto University, Department of Chemistry and Materials Science, Kemistintie 1, 02150 Espoo, Finland. E-mail: tom.blomberg@aalto.fi; tripurari.tripathi@aalto.fi; maarit. karppinen@aalto.fi

$\dagger$ Electronic supplementary information (ESI) available. See DOI: 10.1039/c9ra00582j

\$ The raw/processed data required to reproduce these findings are partly included in the ESI section of the manuscript. Additional raw data is available from the authors upon request. problems is to operate the boilers with lower steam temperatures, but that lowers the efficiency of the Rankine cycle leading to higher emission factors per unit of electricity produced.

Potassium behaviour in the boiler has been identified as the major cause of slagging, fouling and corrosion in biomass fired boilers. ${ }^{6}$ Potassium is found associated in the fuel moisture as water soluble salts, or reacted with the organic functional groups (carboxylic, alkoxy, phenolic) of the lignocellulosic matrix. ${ }^{7}$ During combustion, potassium is released in the gas phase as elemental potassium, potassium chloride or potassium hydroxide as measured by mass spectrometric or optical methods. ${ }^{8-10}$ Due to its extreme reactivity, elemental potassium is expected to react to compounds in the vicinity of the biomass particle it is released from. Therefore, the major gas phase potassium compounds in the biomass boiler flue gases are $\mathrm{KCl}(\mathrm{g})$ and $\mathrm{KOH}(\mathrm{g})$. These compounds may react further with other fuel elements, such as silicon or sulphur to form potassium silicates or potassium sulphate. $\mathrm{K}_{2} \mathrm{O}-\mathrm{SiO}_{2}$ silicate formation plays a major role in deposit formation in the furnace (slagging) and in bed agglomeration issues in fluidized bed 
boilers, where silica containing sand is often used as the bed material. ${ }^{11-13}$ Formation of $\mathrm{K}_{2} \mathrm{SO}_{4}$ plays a major role in aerosol and deposit formation further downstream of the boiler. ${ }^{\mathbf{1 4 , 1 5}}$ $\mathrm{K}_{2} \mathrm{SO}_{4}$ formation may decrease the corrosion rate of the heat exchangers forming a less corrosive deposit than $\mathrm{KCl}$ or $\mathrm{KOH} /$ $\mathrm{K}_{2} \mathrm{CO}_{3}$. Its formation may however, also increase fouling rate of the heat exchangers forming tenuous deposits that are difficult to be removed by soot blowing, even though the corrosion rate under the deposits may still be low. ${ }^{\mathbf{1 6 , 1 7}}$ During their path through the boiler, $\mathrm{KCl}(\mathrm{g})$ and $\mathrm{KOH}(\mathrm{g})$ in the flue gases condense out when the gas temperature is decreased below their dew points. Condensation can happen directly on the heat exchanger surfaces or on the ash particles present in the flue gas flow. Purely homogeneous nucleation is also possible in conditions where the flue gas does not contain enough foreign surfaces that can act as nucleation sites for heterogeneous nucleation. ${ }^{\mathbf{1 8}, 19}$ After condensation $\mathrm{KCl}(\mathrm{s}, \mathrm{l})$ can react heterogeneously further to $\mathrm{K}_{2} \mathrm{SO}_{4}(\mathrm{~s}, \mathrm{l})$ and $\mathrm{KOH}(\mathrm{s}, \mathrm{l})$ can react to $\mathrm{K}_{2} \mathrm{SO}_{4}(\mathrm{~s}, \mathrm{l}), \mathrm{KCl}(\mathrm{s}, \mathrm{l})$ or $\mathrm{K}_{2} \mathrm{CO}_{3}(\mathrm{~s}, 1)$ as predicted by thermodynamic stabilities of the compounds. ${ }^{\mathbf{2 0}, 21}$

$\mathrm{KCl}$ induced corrosion of $\mathrm{Fe}-\mathrm{Cr}$ steels has been studied extensively in the scientific literature..$^{22-28}$ Recently, the effect of $\mathrm{K}_{2} \mathrm{CO}_{3}$ on the high temperature corrosion has gained more interest. It appears both potassium and chlorine are important in the corrosion reactions with steels. It has been suggested that potassium can initiate the destruction of the protective oxide, but chlorine is needed to sustain the corrosion. ${ }^{\mathbf{2 9}, 30} \mathrm{KOH}$ induced corrosion has not been extensively studied in the context of high temperature corrosion in biomass fired boilers, but earlier studies have shown that $\mathrm{Fe}-\mathrm{Cr}$ alloys are unsuitable for service in $\mathrm{KOH}$ containing high temperature environments. ${ }^{31-33}$ Earlier work of the author on the elemental balances of the deposit forming elements in biomass based fuels suggest that $\mathrm{KOH}(\mathrm{g})$ condensation may be more important in fouling and corrosion than has previously been thought. The details of $\mathrm{K}_{2} \mathrm{CO}_{3}(\mathrm{~s}, \mathrm{l})$ formation on the heat exchanger surfaces has not been clarified yet, but its formation has been predicted by thermodynamics when the $(\mathrm{Cl}(\mathrm{g})+2 \mathrm{~S}(\mathrm{~g}))$ molar content in the flue gases is lower than the molar $\mathrm{K}(\mathrm{g})$ content. $\mathrm{K}_{2} \mathrm{CO}_{3}(\mathrm{~s}, \mathrm{l})$ is formed on the heat exchanger surfaces likely via a surface reaction of adsorbed $\mathrm{KOH}\left(\right.$ ads.) with $\mathrm{CO}_{2}(\mathrm{~g})$. Homogeneous formation of $\mathrm{K}_{2} \mathrm{CO}_{3}(\mathrm{~g})$ in the gas phase, followed by condensation of $\mathrm{K}_{2} \mathrm{CO}_{3}(\mathrm{~g})$ is less likely, because of the thermodynamic instability of $\mathrm{K}_{2} \mathrm{CO}_{3}(\mathrm{~g}) \cdot{ }^{34,35} \mathrm{~K}_{2} \mathrm{CO}_{3}(\mathrm{~s}, \mathrm{l})$ has also been directly detected in some boiler deposits. ${ }^{17}$ In this work we studied in detail the reactivity of $\mathrm{KCl}$ and $\mathrm{KOH}$ towards $\mathrm{Cr}_{2} \mathrm{O}_{3}$ and $\mathrm{Fe}_{2} \mathrm{O}_{3}$, the protective oxide components formed on the $\mathrm{Fe}-\mathrm{Cr}$ alloys in high temperature oxidizing service conditions. The results may also be of interest for chromite ore roasting by $\mathrm{KOH}$ and for understanding corrosion of $\mathrm{Cr}_{2} \mathrm{O}_{3}$ containing refractory bricks in potassium and chlorine containing environments. ${ }^{36-38}$

\section{Experimental}

\subsection{Preparation of the mixtures and furnace exposures}

$\mathrm{KOH}-\mathrm{Cr}_{2} \mathrm{O}_{3}, \mathrm{KCl}-\mathrm{Cr}_{2} \mathrm{O}_{3}, \mathrm{KOH}-\mathrm{Fe}_{2} \mathrm{O}_{3}, \mathrm{KCl}-\mathrm{Fe}_{2} \mathrm{O}_{3}$ and $\mathrm{K}_{2} \mathrm{CrO}_{4}-$ $\mathrm{Cr}_{2} \mathrm{O}_{3}$ mixtures were prepared by mixing known amounts of powders in a $10 \mathrm{ml}$ glass bottle and manually shaking the bottles for approximately $30 \mathrm{~s}$. $\mathrm{KOH}$ was from Sigma Aldrich technical grade $\geq 85 \%$, KCl from Alfa Aesar, ACS grade 99$100.5 \%, \mathrm{~K}_{2} \mathrm{CrO}_{4}$ from Merck, EMSURE®, ACS grade $\geq 99.5 \%$, $\mathrm{Cr}_{2} \mathrm{O}_{3}$ from E. Merck, grade unknown and $\mathrm{Fe}_{2} \mathrm{O}_{3}$ from Johnson Matthey Chemicals, Specpure ${ }^{\circledR}$ grade. All powders were weighted with Sartorius CPA225D analytical balance. Larger agglomerates of $\mathrm{KCl}, \mathrm{KOH}$ and $\mathrm{K}_{2} \mathrm{CrO}_{4}$ were grinded manually in a mortar before mixing with the $\mathrm{Cr}_{2} \mathrm{O}_{3}$ or $\mathrm{Fe}_{2} \mathrm{O}_{3}$ powder. $\mathrm{Cr}_{2} \mathrm{O}_{3}$ and $\mathrm{Fe}_{2} \mathrm{O}_{3}$ powders seemed visually homogeneous without agglomerates and were used without any pre-grinding. $\mathrm{KCl} / \mathrm{Cr}_{2} \mathrm{O}_{3}, \mathrm{KCl} / \mathrm{Fe}_{2} \mathrm{O}_{3}$ or $\mathrm{KOH} / \mathrm{Cr}_{2} \mathrm{O}_{3}, \mathrm{KOH} / \mathrm{Fe}_{2} \mathrm{O}_{3}$ molar ratios were 1 and $\mathrm{K}_{2} \mathrm{CrO}_{4} / \mathrm{Cr}_{2} \mathrm{O}_{3}$ molar ratio was 0.5 in order to have the same $\mathrm{K} / \mathrm{metal}$ molar ratio in all of the mixtures. A $10 \mathrm{~g}$ batch of each mixture was prepared in one go in a screw cap sealed bottle. From the $10.0 \mathrm{~g}$ batch bottles, $1.00 \mathrm{~g}$ samples were weighted to a $10 \mathrm{ml}$ sintered $\mathrm{Al}_{2} \mathrm{O}_{3}$ crucible and then loaded immediately in a muffle furnace (Nabertherm P330) that was at the isothermal exposure temperature $\left(100-800{ }^{\circ} \mathrm{C}\right)$. The samples were exposed in the furnace for 2 hours in ambient air atmosphere. After furnace exposures, the samples were cooled in ambient air so that handling of the crucible was possible with nitrile gloves (5-10 $\mathrm{min}$ ) and then transferred to glass bottles that were sealed with screw caps. Then the samples were placed in a desiccator cabin for storage. During the analyses, the sample exposure times to ambient air before starting the analyses were minimized by opening the cap and preparing the sample from the bottle only just before starting the analysis. However, the XRD analysis took approximately an hour per sample, therefore possible reactions during the analysis with ambient air could not be completely eliminated. $\mathrm{KOH}$ especially is known to be highly hygroscopic and reactive towards $\mathrm{CO}_{2}$ during exposure to ambient air.

\subsection{Qualitative determination of $\mathrm{CrO}_{4}{ }^{2-}$ and $\mathrm{Cr}_{2} \mathrm{O}_{7}{ }^{2-}$}

$20 \mathrm{ml}$ glass bottles were filled almost full with ion exchanged water. Then $0.10 \mathrm{~g}$ of each sample was added to the already water filled bottle. The bottles were not agitated by any means in order to let the sample powder sediment to the bottom of the bottle by gravity. The samples were left to stand overnight. The characteristic yellow colour of the $\mathrm{CrO}_{4}{ }^{2-}$ ion started to appear immediately after adding the sample powder and the intensity of the colour increased with time. The sample bottles were then photographed to record the characteristic yellow colour of $\mathrm{CrO}_{4}{ }^{2-}$ and the orange colour of $\mathrm{Cr}_{2} \mathrm{O}_{7}{ }^{2-}$.

\subsection{Qualitative determination of colourful Fe-complex ions}

$20 \mathrm{ml}$ glass bottles were filled almost full with ion exchanged water. Then $0.10 \mathrm{~g}$ of each sample was added to the already water filled bottle. The bottles were not agitated by any means in order to let the sample powder sediment to the bottom of the bottle by gravity. The samples were let to stand still overnight. All the solutions were colourless indicating no signs of water soluble $\mathrm{FeCl}_{3}$ (yellow to orange) or $\mathrm{K}_{2} \mathrm{FeO}_{4}\left(\mathrm{FeO}_{4}{ }^{2-}\right.$ ion is purple) in the samples in concentrations high enough to be visible to the naked eye. 


\subsection{XRD measurements}

XRD analysis was done with PANalytical X'pert Pro PW 3040/60 powder diffraction spectrometer with monochromated $\mathrm{Cu}$ Kalpha X-ray source ( $\alpha=1.5406 \AA$ ). Samples were first grinded manually in a mortar to make a visually homogeneous powder. Then the sample holder was filled evenly with the powder, pressed against a flat surface to level the sample surface with the sample holder top surface and then XRD $\theta-2 \theta$ scans were recorded from $10-90^{\circ}$. The automatic phase identification algorithm of the X'Pert HighScore Plus program was used for preliminary identification of the phases. Then the results were checked manually and the most likely crystalline phases where manually identified using the JCPDS cards. The XRD cards used for phase identifications were 00-021-0645 for $\mathrm{KOH}, 00-011$ 0655 for $\mathrm{K}_{2} \mathrm{CO}_{3} \cdot 1.5 \mathrm{H}_{2} \mathrm{O}$, 00-015-0365 for $\mathrm{K}_{2} \mathrm{CrO}_{4}$, 04-007-3113 for KCl, 01-078-5435 for $\mathrm{Cr}_{2} \mathrm{O}_{3}$, 04-012-4476 for $\mathrm{K}_{2} \mathrm{Cr}_{2} \mathrm{O}_{7}$, 01-0850599 for $\mathrm{Fe}_{2} \mathrm{O}_{3}$, 00-039-0892 for $\mathrm{KFeO}_{2}$, 00-039-1106 for $\mathrm{K}_{2} \mathrm{Fe}_{4} \mathrm{O}_{7}$ and 01-078-6089 for $\mathrm{K}_{1.75} \mathrm{Fe}_{1.25} \mathrm{O}_{4}$.

\subsection{UV/VIS spectroscopic measurements of $\mathrm{CrO}_{4}{ }^{2-}$}

Approximately $0.20 \mathrm{~g}$ of sample powder was mixed with $20 \mathrm{ml}$ of room temperature ion exchanged water. The solution was first stirred in a beaker with a magnetic stirrer for $15 \mathrm{~min}$. Then the solution was filtered using qualitative filter paper, 410 (Cat. No. 516-0802 from VWR), the residue washed two times with $10 \mathrm{ml}$ of room temperature ion exchanged water. Then the filtrates were transferred to $50 \mathrm{ml}$ volumetric flasks and the flask was filled to the mark with ion exchanged water and mixed. The $\mathrm{CrO}_{4}{ }^{2-}$ concentrations of the filtrates were determined by UV/ VIS spectroscopy using Shimadzu UV-2600 spectrophotometer and polymethylmethacrylate cuvettes. Absorbance at $372 \mathrm{~nm}$ was used for $\mathrm{CrO}_{4}{ }^{2-}$. It is not possible to determine $\mathrm{Cr}_{2} \mathrm{O}_{7}{ }^{2-}$ and $\mathrm{CrO}_{4}{ }^{2-}$ separately, because they are in equilibrium with each other in a water solution. This equilibrium depends on the $\mathrm{pH}$ and $\mathrm{p}[\mathrm{Cr}]$ of the solution. With $\mathrm{pH}$ values $>6.7$, the $\mathrm{CrO}_{4}{ }^{2-}$ ion is reported to be the stable form regardless of the Cr-concentration. ${ }^{39}$ Therefore, the $\mathrm{K}_{2} \mathrm{Cr}_{2} \mathrm{O}_{7}$ possibly present originally in the samples was detected as $\mathrm{CrO}_{4}{ }^{2-}$ and the concentration determined reflects the sum of $\mathrm{K}_{2} \mathrm{CrO}_{4}+\mathrm{K}_{2} \mathrm{Cr}_{2} \mathrm{O}_{7}$ originally in the sample. The $\mathrm{pH}$ values of the filtrates were determined to be $\geq 7$ with a pH indicator sticks (Fisher Scientific number 10642751). All the $\mathrm{KCl}$ based samples had $\mathrm{pH}=7$ and $\mathrm{KOH}$ based samples had $\mathrm{pH}=7$ in samples exposed at $\geq 500{ }^{\circ} \mathrm{C}$ and $\mathrm{pH}$ 8-12 in samples exposed at $\leq 400{ }^{\circ} \mathrm{C}$. The higher $\mathrm{pH}$ with low temperature samples in case of $\mathrm{KOH}$ mixtures was caused by the $\mathrm{KOH}$ that was not reacted to $\mathrm{K}_{2} \mathrm{CrO}_{4}$, but formed $\mathrm{K}_{2} \mathrm{CO}_{3} \cdot 1.5 \mathrm{H}_{2} \mathrm{O}$ during the furnace/ambient exposures. When dissolving in water, $\mathrm{K}_{2} \mathrm{CO}_{3} \cdot 1.5 \mathrm{H}_{2} \mathrm{O}$ results in a basic solution. Concentration standards were prepared by dissolving known amounts of $\mathrm{K}_{2} \mathrm{CrO}_{4}$ powder to ion exchanged water in $50 \mathrm{ml}$ volumetric flasks (ESI $\dagger$ ). Then the absorbance of the standards were measured and linear concentration-absorbance curves were established. Then the absorbance of the sample filtrates were measured and the concentrations were determined using the standard curves. In cases where the sample had $\mathrm{CrO}_{4}{ }^{2-}$ concentration so high that the absorbance was higher than the standards, the sample was diluted with pure water in volumetric flasks with 1 : 10 or 1 : 20 dilution ratios, which ever was suitable to bring the absorbance value in between the standards. Molar ratios reacted to $\mathrm{K}_{2} \mathrm{CrO}_{4}$ and $\mathrm{K}_{2} \mathrm{Cr}_{2} \mathrm{O}_{7}$ were calculated as follows:

$$
\begin{aligned}
& \frac{\mathrm{K}_{2} \mathrm{CrO}_{4}+\mathrm{K}_{2} \mathrm{Cr}_{2} \mathrm{O}_{7}}{\mathrm{~K}_{2} \mathrm{CrO}_{4} \text { (theor.) }} \\
& \quad=\frac{2\left[\mathrm{CrO}_{4}{ }^{2-}\right] V}{\left(\frac{m}{\frac{M_{\mathrm{KCl}}}{M_{\mathrm{KCl}}+M_{\mathrm{Cr}_{2} \mathrm{O}_{3}}} M_{\mathrm{KCl}}+\frac{M_{\mathrm{Cr}_{2} \mathrm{O}_{3}}}{M_{\mathrm{KCl}}+M_{\mathrm{Cr}_{2} \mathrm{O}_{3}}} M_{\mathrm{Cr}_{2} \mathrm{O}_{3}}}\right)}
\end{aligned}
$$

$\frac{\mathrm{K}_{2} \mathrm{CrO}_{4}+\mathrm{K}_{2} \mathrm{Cr}_{2} \mathrm{O}_{7}}{\mathrm{~K}_{2} \mathrm{CrO}_{4} \text { (theor.) }}$

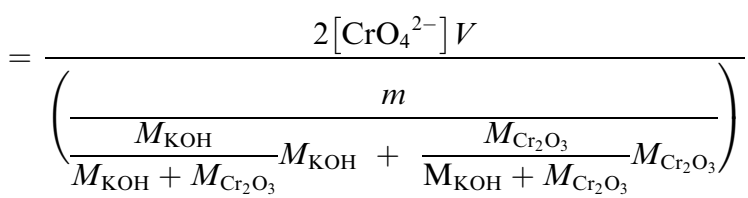

$V=$ volume, $\mathrm{l} ; m=$ sample mass, $\mathrm{g} ; M=$ molar mass, $\mathrm{g} \mathrm{mol}^{-1}$; $\left[\mathrm{CrO}_{4}{ }^{2-}\right]=\mathrm{CrO}_{4}{ }^{2-}$ ion concentration, $\mathrm{mol} \mathrm{l}^{-1}$.

Error estimation of the above described method for $\mathrm{K}_{2} \mathrm{CrO}_{4}$ determination was done by running a few duplicate runs with $\mathrm{KOH}+\mathrm{Cr}_{2} \mathrm{O}_{3}$ mixtures ( 2 at 300 and $400{ }^{\circ} \mathrm{C}$ exposure temperatures). Because of the small number of duplicate samples, error was estimated with the range rather than with statistical methods. The error range ( $\max -\mathrm{min})$ of the method was found to be about 0.08 (or $8 \%$-points). This error value was assumed to be similar at other exposure temperatures and also for the leaching tests described below for $\mathrm{Fe}^{3+}$.

\subsection{UV/VIS spectroscopic measurements of $\mathrm{Fe}^{3+}$}

2.6.1 Water soluble $\mathrm{Fe}^{3+}$. Approximately $0.20 \mathrm{~g}$ of sample powder was mixed with $20 \mathrm{ml}$ of room temperature ion exchanged water. The solution was stirred in a beaker with a magnetic stirrer for $15 \mathrm{~min}$. Then the solution was filtered using qualitative filter paper 410 (Cat. No. 516-0802 from VWR), the residue washed two times with $10 \mathrm{ml}$ of room temperature ion exchanged water. Then the filtrates were transferred to $50 \mathrm{ml}$ volumetric flasks and the flask was filled to the mark with ion exchanged water and mixed. The $\mathrm{Fe}^{3+}$ concentrations of the filtrates were determined by UV/VIS spectroscopy using Shimadzu UV-2600 spectrophotometer. Absorbance at $225 \mathrm{~nm}$ was used for $\mathrm{Fe}^{3+} . \mathrm{Fe}^{3+}$ ion in a water solution is present as $\mathrm{Fe}^{3+}$, $\mathrm{Fe}(\mathrm{OH})^{2+}$ and $\mathrm{Fe}(\mathrm{OH})_{2}{ }^{+}$ions or as non-water soluble $\mathrm{Fe}(\mathrm{OH})_{3}$ precipitate, depending on the $\mathrm{pH}$ of the solution. ${ }^{40}$ The $\mathrm{pH}$ values of the filtrates were determined with a $\mathrm{pH}$ indicator sticks (Fisher Scientific number 10642751). All the KCl based samples had $\mathrm{pH}=7$ and all the $\mathrm{KOH}$ based samples had $\mathrm{pH}=$ 12. The high $\mathrm{pH}$ value over the entire exposure temperature in case of $\mathrm{KOH}$ based samples indicate that they may have contained some unreacted $\mathrm{KOH} / \mathrm{K}_{2} \mathrm{CO}_{3}$ or then the higher $\mathrm{pH}$ at firing temperatures $\geq 500{ }^{\circ} \mathrm{C}$ (which did not reveal any $\mathrm{KOH} /$ $\mathrm{K}_{2} \mathrm{CO}_{3}$ residues by XRD) was originated from the dissolution of 


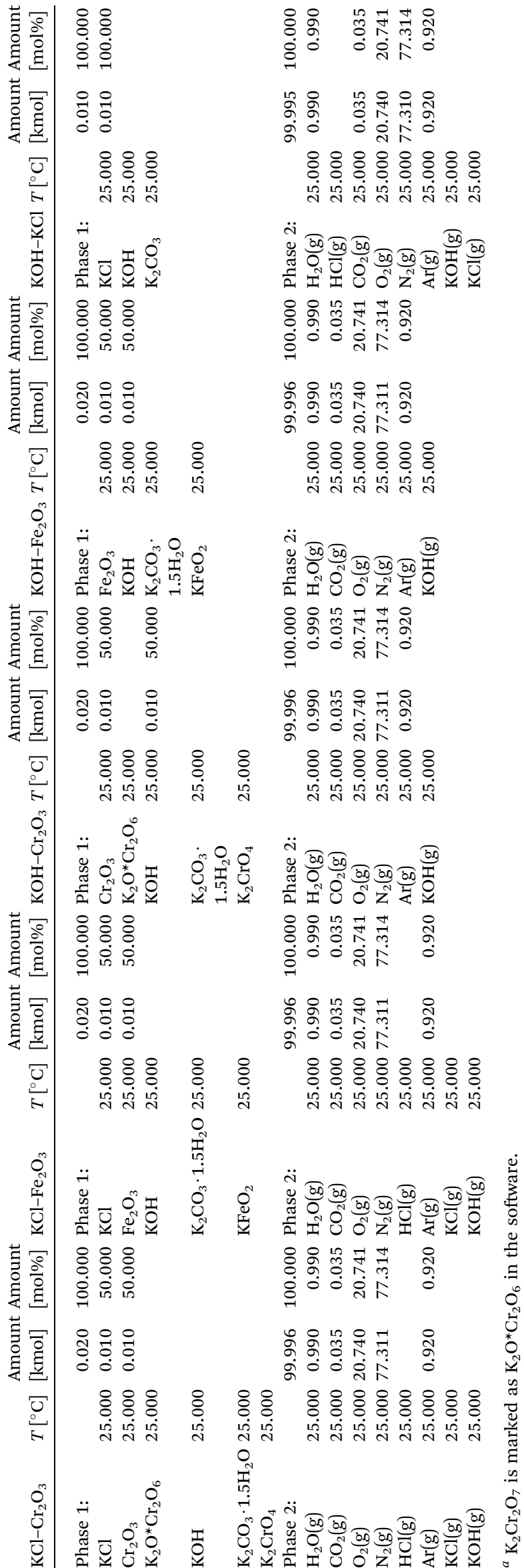

$\mathrm{KFeO}_{2}\left(\mathrm{KFeO}_{2}+2 \mathrm{H}_{2} \mathrm{O}=\mathrm{K}^{+}+\mathrm{Fe}^{3+}+4 \mathrm{OH}^{-}\right)$. In order to shift the equilibrium so that all the dissolved $\mathrm{Fe}(\mathrm{III})$ was in the $\mathrm{Fe}^{3+}$ state, the filtrates were buffered to $\mathrm{pH}=1$ by mixing $1: 1$ ratio of sample with a solution to $1 \mathrm{~mol} \mathrm{l}^{-1} \mathrm{HCl}(1: 2$ dilution). This $\mathrm{pH}$ stabilized solution was then used to fill the quartz cuvette in the UV/VIS absorption measurements. The added Cl-ion can also form complex ions with $\mathrm{Fe}$ in the form $\mathrm{Fe}\left(\mathrm{H}_{2} \mathrm{O}\right)_{6-x}(\mathrm{Cl})_{x}{ }^{3-x}$. Concentration standards were prepared by dissolving known amounts of $\mathrm{FeCl}_{3} \cdot 6 \mathrm{H}_{2} \mathrm{O}$ powder to ion exchanged water and diluting $(\mathrm{ESI} \dagger)$. The $\mathrm{pH}$ of the standards were buffered to 1 with $1 \mathrm{~mol} \mathrm{l}^{-1} \mathrm{HCl}$ before measurement as with the samples. Then the absorbance of the standards were measured and linear concentration-absorbance curves were established. Then the absorbance of the sample filtrates were measured and the concentrations were determined using the standard curves. Molar ratios reacted to $\mathrm{KFeO}_{2}$ were calculated as follows:

$\mathrm{KFeO}_{2}$

$\overline{\mathrm{KFeO}_{2} \text { (theor.) }}$

$$
=\frac{\left[\mathrm{Fe}^{3+}\right] V}{\left(\frac{m}{\frac{M_{\mathrm{KCl}}}{M_{\mathrm{KCl}}+M_{\mathrm{Fe}_{2} \mathrm{O}_{3}}} M_{\mathrm{KCl}}+\frac{M_{\mathrm{Fe}_{2} \mathrm{O}_{3}}}{M_{\mathrm{KCl}}+M_{\mathrm{Fe}_{2} \mathrm{O}_{3}}} M_{\mathrm{Fe}_{2} \mathrm{O}_{3}}}\right)}
$$

$\mathrm{KFeO}_{2}$

$\overline{\mathrm{KFeO}_{2} \text { (theor.) }}$

$$
=\frac{\left[\mathrm{Fe}^{3+}\right] V}{\left(\frac{m}{\frac{M_{\mathrm{KOH}}}{M_{\mathrm{KOH}}+M_{\mathrm{Fe}_{2} \mathrm{O}_{3}}} M_{\mathrm{KOH}}+\frac{M_{\mathrm{Fe}_{2} \mathrm{O}_{3}}}{M_{\mathrm{KOH}}+M_{\mathrm{Fe}_{2} \mathrm{O}_{3}}} M_{\mathrm{Fe}_{2} \mathrm{O}_{3}}}\right)}
$$

$V=$ volume, $\mathrm{l} ; m=$ sample mass, $\mathrm{g} ; M=$ molar mass, $\mathrm{g} \mathrm{mol}^{-1}$; $\left[\mathrm{Fe}^{3+}\right]=\mathrm{Fe}^{3+}$ ion concentration, mol l ${ }^{-1}$.

2.6.2 Acid soluble $\mathrm{Fe}^{3+}$. The analysis was done in a similar way as has been discussed for the $\mathrm{H}_{2} \mathrm{O}$ soluble $\mathrm{Fe}^{3+}$ determination, except that the $15 \mathrm{~min}$ leaching steps were done in $20 \mathrm{ml}$ of $1 \mathrm{~mol} \mathrm{l}^{-1} \mathrm{HCl}$ in water solutions instead of pure water. Also the washing of the filtration residue was done with $\mathrm{HCl}$ containing water $\left(\approx 0.1 \mathrm{~mol} \mathrm{l}^{-1} \mathrm{HCl}, \mathrm{pH}=1\right)$ instead of pure water. This prevented the precipitation of $\mathrm{Fe}(\mathrm{OH})_{3}$ that was possible in the water leaching steps, where the $\mathrm{pH}$ values of the filtrates were $\geq 7$. In case of $1 \mathrm{M} \mathrm{HCl} \mathrm{leaching,} \mathrm{some} \mathrm{filtrates} \mathrm{had} \mathrm{a} \mathrm{yellow}$ colour visible already to a naked eye, indicating that indeed the acid leaching resulted in much higher dissolution of the reaction products compared to $\mathrm{H}_{2} \mathrm{O}$ leaching. All the filtrates had a $\mathrm{pH}$ value of 1 , measured with $\mathrm{pH}$ indicator sticks (Fisher Scientific number 10642751). Because the $\mathrm{pH}$ of the filtrates were stabilized to one already during the leaching step, they were used directly to fill the quartz cuvette in the UV/VIS absorption measurements. In cases where the sample had $\mathrm{Fe}^{3+}$ concentration so high that the absorbance was higher than the standards, the sample was diluted in volumetric flasks with $1: 2,1: 50$ or $1: 100$ dilution ratios, which ever was suitable to bring the absorbance value in between the standards. In the $1: 50$ and $1: 100$ dilution cases, the dilution was done by 


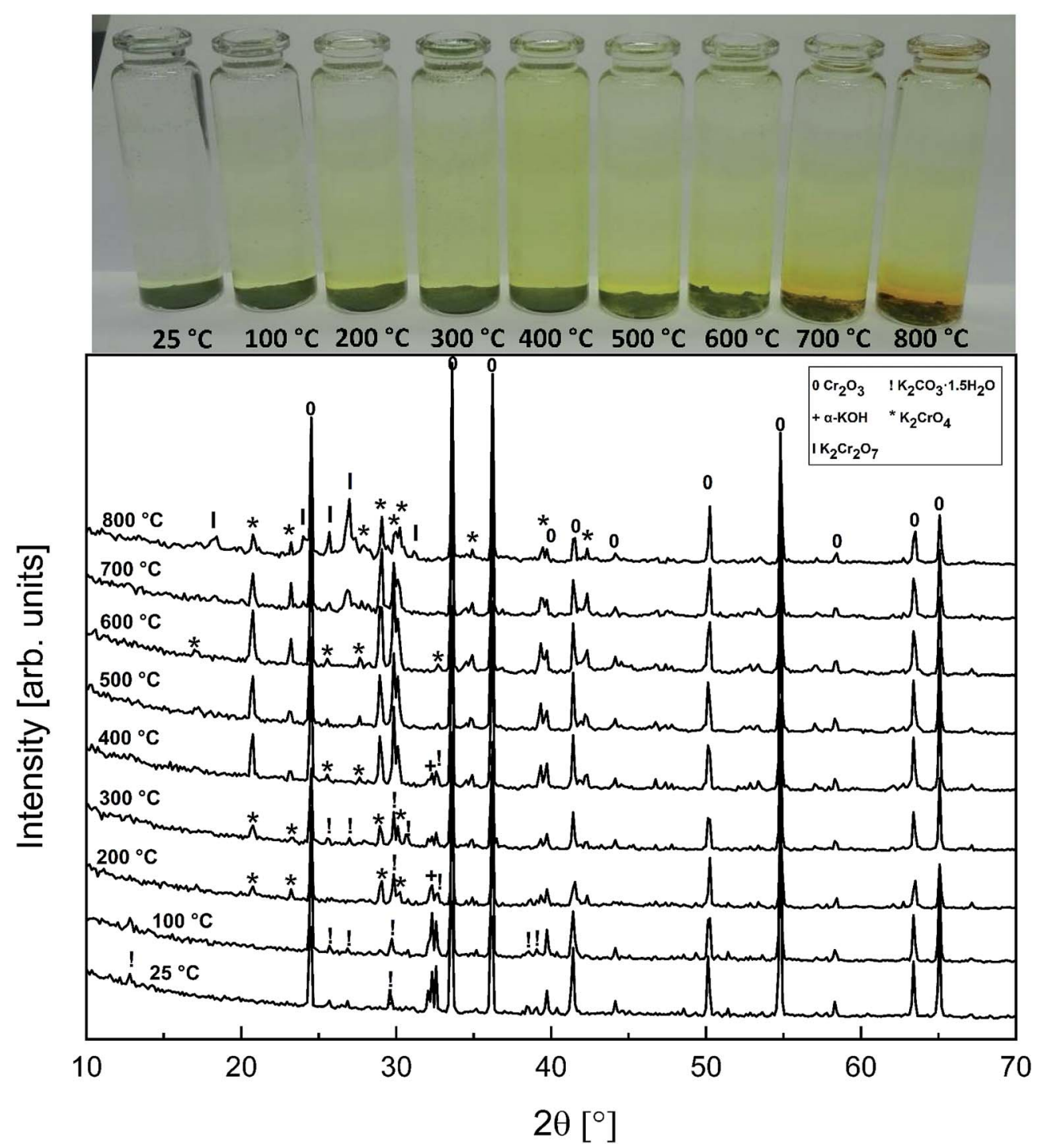

Fig. $1 \mathrm{XRD}$ patterns and appearance of the water solutions on top of the $\mathrm{KOH}-\mathrm{Cr}_{2} \mathrm{O}_{3}$ mixtures after furnace exposures.

adding $1 \mathrm{ml}$ of sample, then $5 \mathrm{ml}$ of $1 \mathrm{~mol} \mathrm{l}^{-1} \mathrm{HCl}$, and then filling the volumetric flask with pure $\mathrm{H}_{2} \mathrm{O}$.

\subsection{Thermodynamic calculations}

HSC v6.12 Gibbs energy minimization software was used in the thermodynamic calculations. ${ }^{\mathbf{4 1}}$ The input files for the calculations are presented in Table 1. Air composition $^{42}$ with $\approx 0.99 \mathrm{~mol} \% \mathrm{H}_{2} \mathrm{O}$ vapor $\left(\mathrm{RH} \approx 32 \%\right.$ at $25{ }^{\circ} \mathrm{C}$ ) was used to simulate the humid ambient gas phase in the muffle furnace. In case of $\mathrm{KCl}$ based systems, $\mathrm{HCl}(\mathrm{g})$ was added as the possible gas phase Cl-compound released in the reactions. Note that each gas phase component in the atmosphere has at least several times higher absolute amounts than any of the solid phase components. This assures that the amount of the formed products was never limited by the amount of the gas phase component, thus simulating an open ambient system. The calculated systems were kept as simple as possible. Therefore, in addition to the reactants, only the phases identified in the
$\mathrm{XRD}$ analysis were added to the solid phase input file. In the case of $\mathrm{Fe}_{2} \mathrm{O}_{3}$ systems, $\mathrm{K}_{2} \mathrm{Fe}_{4} \mathrm{O}_{7}$ was detected by XRD in the sample with the highest exposure temperature with $\mathrm{KOH}$, but unfortunately it was not found in the HSC v6.12 database and could not be included in the thermodynamic calculation.

\section{Results}

\section{1 $\mathrm{KOH}-\mathrm{Cr}_{2} \mathrm{O}_{3}$ system}

The powder XRD analysis of the system after furnace exposures is shown in Fig. 1. It appears that $\mathrm{KOH}$ reacted partially with the air in the furnace and formed $\mathrm{K}_{2} \mathrm{CO}_{3} \cdot 1.5 \mathrm{H}_{2} \mathrm{O}$ in samples exposed to furnace temperatures below $500{ }^{\circ} \mathrm{C}$. Samples exposed to $500{ }^{\circ} \mathrm{C}$ or higher firing temperatures did not contain any residual $\mathrm{K}_{2} \mathrm{CO}_{3} \cdot 1.5 \mathrm{H}_{2} \mathrm{O}$ or $\mathrm{KOH}$. This was also reflected by the $\mathrm{pH}$ of the water soluble filtrates as explained in the experimental section. It seems that the reaction of $\mathrm{KOH}$ with $\mathrm{Cr}_{2} \mathrm{O}_{3}$, forming $\mathrm{K}_{2} \mathrm{CrO}_{4}$ is not fast enough below $500{ }^{\circ} \mathrm{C}$ and competes 


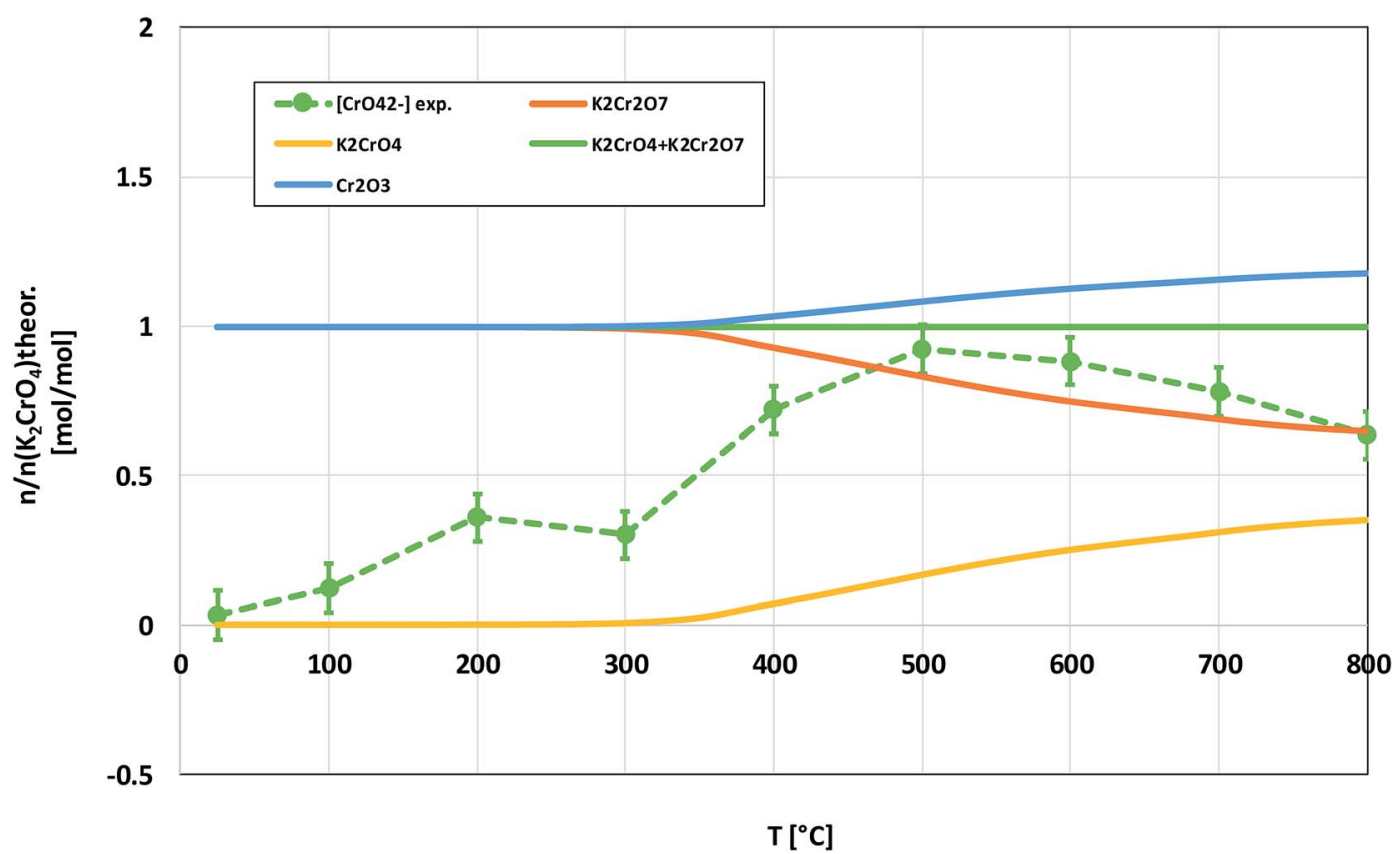

Fig. 2 Comparison of the experimentally determined amount of $\left[\mathrm{CrO}_{4}{ }^{2-}\right]$ in the filtrates with the thermodynamically predicted amount of the reaction products in the $\mathrm{KOH}-\mathrm{Cr}_{2} \mathrm{O}_{3}$ system with pure water leaching.

with $\mathrm{K}_{2} \mathrm{CO}_{3} \cdot 1.5 \mathrm{H}_{2} \mathrm{O}$ formation in the experimental conditions used. According to XRD analysis, $\mathrm{K}_{2} \mathrm{CrO}_{4}$ formation starts already with a solid-solid reaction at $200{ }^{\circ} \mathrm{C}$. Melting point of $\mathrm{KOH}$ is $406{ }^{\circ} \mathrm{C}$, so it appears that there is no need for molten phase to form in the system before $\mathrm{K}_{2} \mathrm{CrO}_{4}$ formation proceeds. The photograph in Fig. 1 reveals the characteristic colour of the $\mathrm{CrO}_{4}{ }^{2-}$ ion already appearing in the water soluble fraction of the products at room temperature exposures. However, this

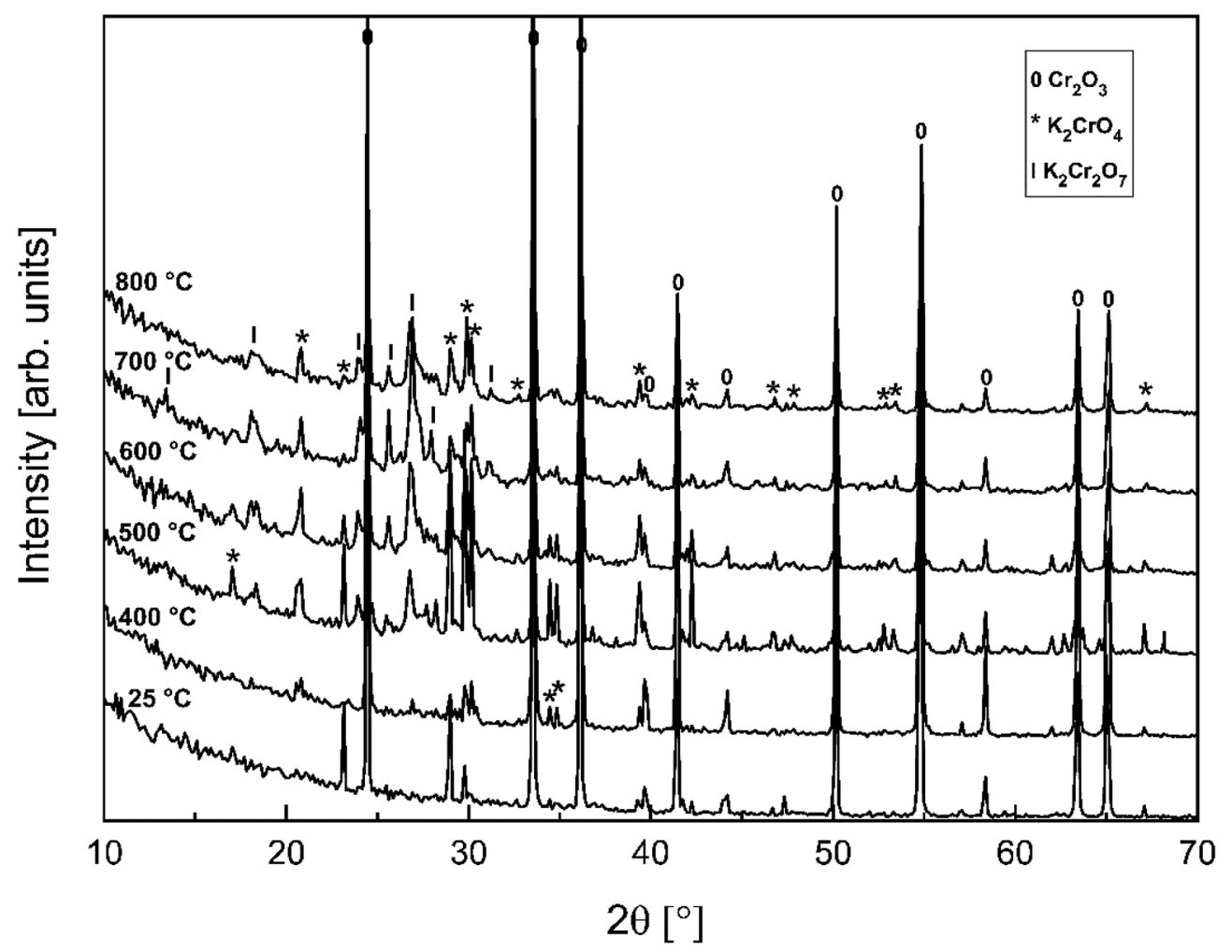

Fig. 3 XRD patterns for the $\mathrm{K}_{2} \mathrm{CrO}_{4}-\mathrm{Cr}_{2} \mathrm{O}_{3}$ mixtures after furnace exposures. 


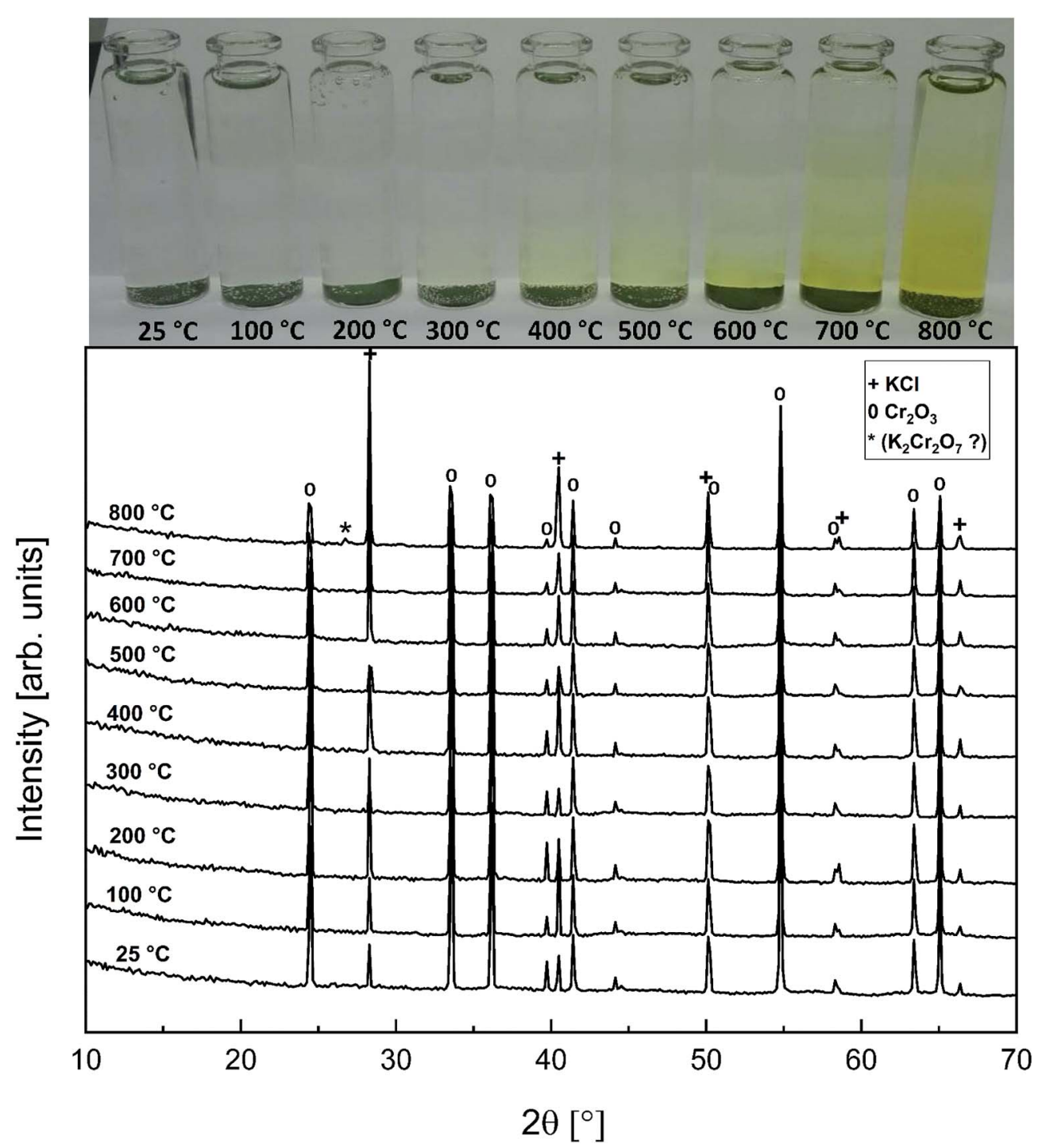

Fig. 4 XRD patterns and appearance of the water solutions on top of the $\mathrm{KCl}-\mathrm{Cr}_{2} \mathrm{O}_{3}$ mixtures after furnace exposures.

$\mathrm{CrO}_{4}{ }^{2-}$ may form from the dissolution of $\mathrm{Cr}_{2} \mathrm{O}_{3}$ in the basic water solution and therefore it is considered that the XRD analysis provides a better estimation of the onset temperature where $\mathrm{K}_{2} \mathrm{CrO}_{4}$ formation starts. The characteristic orange colour of the $\mathrm{Cr}_{2} \mathrm{O}_{7}{ }^{2-}$ ion was detected in samples fired at $700{ }^{\circ} \mathrm{C}$ and $800{ }^{\circ} \mathrm{C} . \mathrm{K}_{2} \mathrm{Cr}_{2} \mathrm{O}_{7}$ was also detected in the XRD analysis at these firing temperatures. Thermodynamic calculations predict $\mathrm{K}_{2} \mathrm{Cr}_{2} \mathrm{O}_{7}$ to be the most stable reaction product throughout the temperature range used as shown in Fig. 2, but its formation appears to be kinetically prevented below $700{ }^{\circ} \mathrm{C}$. The experimental results clearly show that $\mathrm{K}_{2} \mathrm{CrO}_{4}$ formation is kinetically preferred at the studied temperature range and exposure time used. Like explained above, $\mathrm{K}_{2} \mathrm{CrO}_{4}$ formation itself seemed also to be kinetically controlled at temperatures lower than $500{ }^{\circ} \mathrm{C}$. The maximum $\mathrm{CrO}_{4}{ }^{2-}$ amount $(>90 \%$ of the theoretical) in the reaction products was measured at $500{ }^{\circ} \mathrm{C}$ furnace exposure, after which the amount decreased slightly at higher temperatures. Taking into account the experimental errors associated with the $\mathrm{CrO}_{4}{ }^{2-}$ analysis, it is suggested that starting at $500{ }^{\circ} \mathrm{C}$, practically all the $\mathrm{KOH}$ had reacted to $\mathrm{K}_{2} \mathrm{CrO}_{4}$ and that the slightly lower amounts of $\mathrm{CrO}_{4}{ }^{2-}$ detected at higher exposure temperatures can be explained by slight loss of $\mathrm{KOH}$ by evaporation, competing with the reaction with $\mathrm{Cr}_{2} \mathrm{O}_{3}$.

\section{2 $\mathrm{K}_{2} \mathrm{CrO}_{4}-\mathrm{Cr}_{2} \mathrm{O}_{3}$ system}

In order to determine if the $\mathrm{K}_{2} \mathrm{Cr}_{2} \mathrm{O}_{7}$ formation at higher firing temperatures proceeds directly from the reaction with $\mathrm{KOH}$ or via first formation of $\mathrm{K}_{2} \mathrm{CrO}_{4}$ and then further reaction with $\mathrm{Cr}_{2} \mathrm{O}_{3}$, the $\mathrm{K}_{2} \mathrm{CrO}_{4}-\mathrm{Cr}_{2} \mathrm{O}_{3}$ system was studied with XRD analysis. Results are presented in Fig. 3. From the XRD analysis it is clear that $\mathrm{K}_{2} \mathrm{CrO}_{4}$ can react with $\mathrm{Cr}_{2} \mathrm{O}_{3}$ and form $\mathrm{K}_{2} \mathrm{Cr}_{2} \mathrm{O}_{7}$ at exposure temperatures $\geq 500{ }^{\circ} \mathrm{C}$. Therefore, it is suggested that direct reaction of $\mathrm{KOH}$ with $\mathrm{Cr}_{2} \mathrm{O}_{3}$ forms $\mathrm{K}_{2} \mathrm{CrO}_{4}$ and that the formation of $\mathrm{K}_{2} \mathrm{Cr}_{2} \mathrm{O}_{7}$ requires always the $\mathrm{K}_{2} \mathrm{CrO}_{4}$ reaction intermediate to form first. 


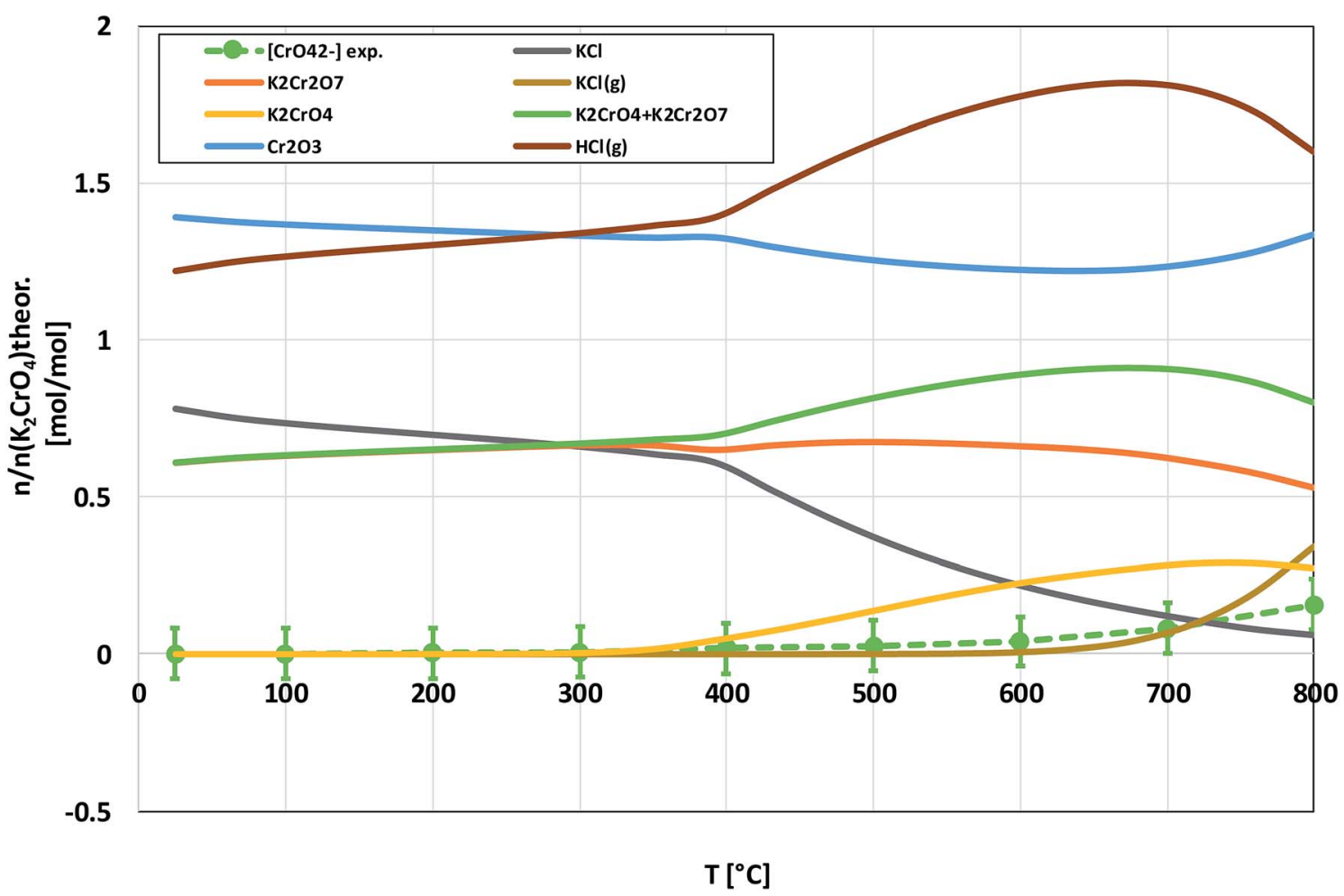

Fig. 5 Comparison of the experimentally determined amount of $\left[\mathrm{CrO}_{4}{ }^{2-}\right]$ in the filtrates with the thermodynamically predicted amount of the reaction products in the $\mathrm{KCl}-\mathrm{Cr}_{2} \mathrm{O}_{3}$ system with pure water leaching.

\section{$3.3 \quad \mathrm{KCl}-\mathrm{Cr}_{2} \mathrm{O}_{3}$ system}

Compared to $\mathrm{KOH}, \mathrm{KCl}$ is substantially less reactive with $\mathrm{Cr}_{2} \mathrm{O}_{3}$. As shown in the XRD analysis in Fig. 4, there were no clear signs of reaction with $\mathrm{Cr}_{2} \mathrm{O}_{3}$ until the highest firing temperature, $800^{\circ} \mathrm{C}$. At $800^{\circ} \mathrm{C}$, an additional peak was detected at $26.95^{\circ}(2 \theta)$. This peak coincides with the (021) reflection of $\mathrm{K}_{2} \mathrm{Cr}_{2} \mathrm{O}_{7}$. However, using only one peak in phase identification is not reliable, but based on the analogy with results from the $\mathrm{KOH}-$ $\mathrm{Cr}_{2} \mathrm{O}_{3}$ and $\mathrm{K}_{2} \mathrm{CrO}_{4}-\mathrm{Cr}_{2} \mathrm{O}_{3}$ systems, $\mathrm{K}_{2} \mathrm{Cr}_{2} \mathrm{O}_{7}$ was considered to be the most likely reaction product at $800{ }^{\circ} \mathrm{C}$. $\mathrm{CrO}_{4}{ }^{2-}$ was detected qualitatively and quantitatively also at lower firing temperatures as shown in Fig. 4 and 5. Thermodynamic calculation predicted again the formation of $\mathrm{K}_{2} \mathrm{Cr}_{2} \mathrm{O}_{7}$ and $\mathrm{K}_{2} \mathrm{CrO}_{4}$ as the major products, but now the discrepancy between the thermodynamic prediction and experimental results was higher than with $\mathrm{KOH}$. $\mathrm{CrO}_{4}{ }^{2-}$ was detected only in samples exposed to firing temperatures $\geq 400{ }^{\circ} \mathrm{C}$ and even at $800{ }^{\circ} \mathrm{C}$ the $\mathrm{CrO}_{4}{ }^{2-}$ amount was only $\approx 16 \%$ of the theoretical maximum.

\section{$3.4 \mathrm{KOH}-\mathrm{Fe}_{2} \mathrm{O}_{3}$ system}

Fig. 6 shows the XRD analysis of the $\mathrm{KOH}-\mathrm{Fe}_{2} \mathrm{O}_{3}$ system. Reaction with $\mathrm{Fe}_{2} \mathrm{O}_{3}$ started at $200{ }^{\circ} \mathrm{C}$ firing temperature, forming $\mathrm{KFeO}_{2}$ as the reaction product. $\mathrm{KFeO}_{2}$ stayed as the major reaction product throughout the temperature range. At $500^{\circ} \mathrm{C}$ an additional peak at $27.95^{\circ}(2 \theta)$ was detected that could not be assigned to $\mathrm{KFeO}_{2}$. This peak was assigned to potassium containing magnetite, $\mathrm{K}_{1.75} \mathrm{Fe}_{1.25} \mathrm{O}_{4}$ that has the maximum intensity powder XRD peak at this position, but with one peak only, the identification remains doubtful. At $800{ }^{\circ} \mathrm{C}$ firing temperature, $\mathrm{K}_{2} \mathrm{Fe}_{4} \mathrm{O}_{7}$ could also be identified as the reaction product in addition to $\mathrm{KFeO}_{2}$. There was no indication of higher oxidation state than +3 reaction products of $\mathrm{Fe}$, such as $\mathrm{K}_{2} \mathrm{FeO}_{4}$. This was consistent with the lack of any colour of the water solutions containing the dissolved reaction products shown in Fig. 6. This result reflects the more favourable tendency of $\mathrm{Cr}$ to adapt oxidation state +6 compared to $\mathrm{Fe}$. The comparison of the measured water soluble and acid soluble $\mathrm{Fe}^{3+}$ amounts with the thermodynamic prediction are presented in Fig. 7. No water soluble $\mathrm{Fe}^{3+}$ was found, but the amount of acid soluble $\mathrm{Fe}^{3+}$ was very close to the thermodynamically predicted amount of $\mathrm{KFeO}_{2}$. This difference in the filtrates as a function of $\mathrm{pH}$ is caused by the fact that either $\mathrm{KFeO}_{2}$ is not soluble in water, or that after initial dissolution of $\mathrm{KFeO}_{2}$, rapid formation of insoluble $\mathrm{Fe}(\mathrm{OH})_{3}$ takes place in the basic solution. The high $\mathrm{OH}^{-}$concentration precipitates the initially dissolved iron and captures it in the filtration residue. In acidic conditions, $\mathrm{Fe}(\mathrm{OH})_{3}$ formation is prevented and $\mathrm{KFeO}_{2}$ was dissolved completely in the 15 min leaching step and the dissolved iron stayed in the solution phase during the filtration step.

\section{$3.5 \quad \mathrm{KCl}-\mathrm{Fe}_{2} \mathrm{O}_{3}$ system}

As with the $\mathrm{KCl}-\mathrm{Cr}_{2} \mathrm{O}_{3}$ system, $\mathrm{KCl}$ turned out to be much less reactive towards $\mathrm{Fe}_{2} \mathrm{O}_{3}$ compared to $\mathrm{KOH}$. There was no sign of any reaction in the XRD analysis or in the visual qualitative analysis of the water soluble reaction products as shown in Fig. 8. Similar to the $\mathrm{KOH}-\mathrm{Fe}_{2} \mathrm{O}_{3}$ case, no water soluble iron was 


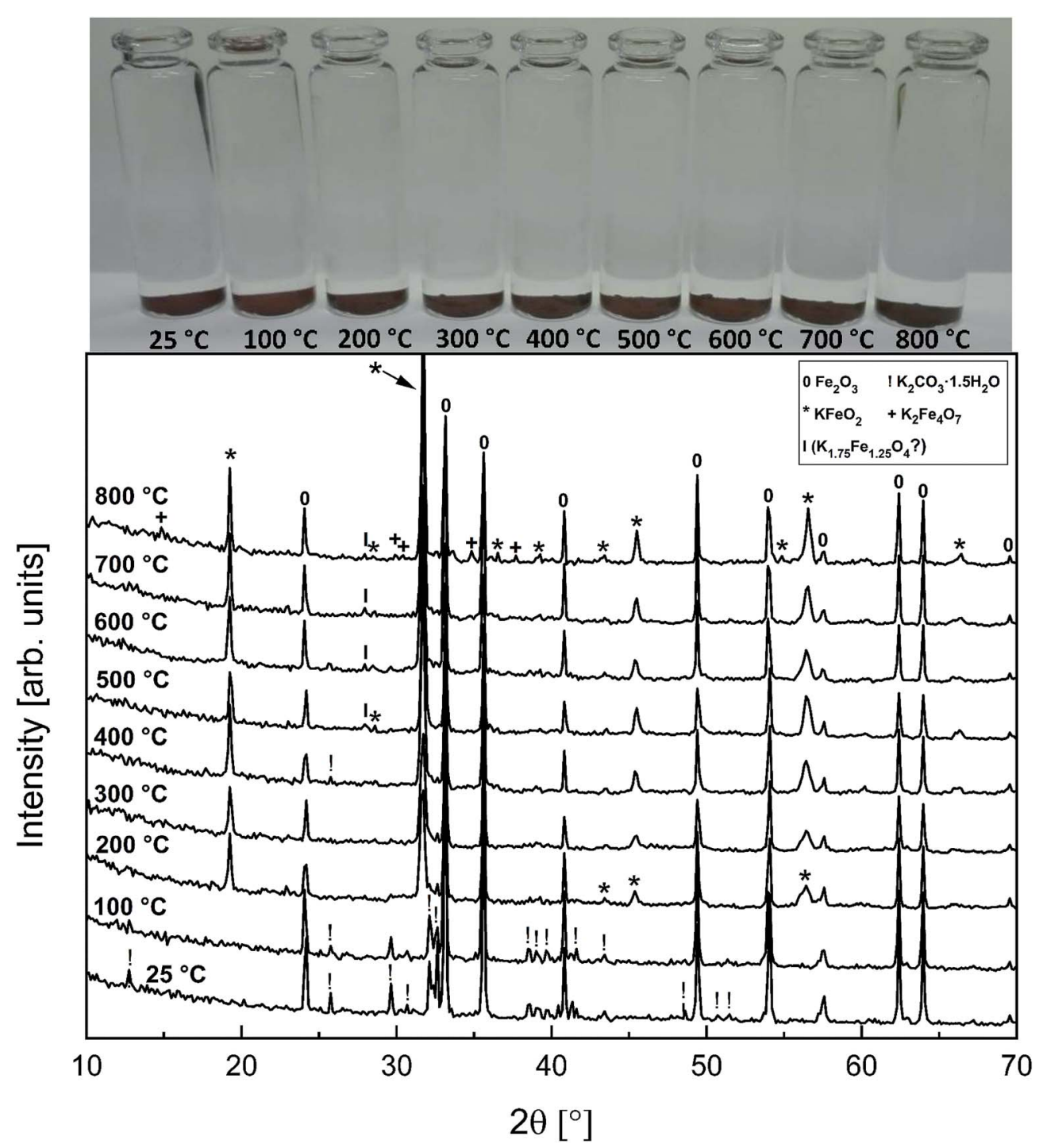

Fig. 6 XRD patterns and appearance of the water solutions on top of the $\mathrm{KOH}-\mathrm{Fe}_{2} \mathrm{O}_{3}$ mixtures after furnace exposures.

found, but now there was only traces of $\mathrm{Fe}^{3+}$ detected even in the acid soluble filtrate. The results agree with thermodynamic equilibrium calculations, which predicted only slight reaction in the $\mathrm{KCl}-\mathrm{Fe}_{2} \mathrm{O}_{3}$ system at temperatures $>600{ }^{\circ} \mathrm{C}$ to form $\mathrm{KFeO}_{2}$ as shown in Fig. 9.

\section{Discussion}

Our results are consistent with the suggestion that the reaction of $\mathrm{KCl}$ with $\mathrm{Cr}_{2} \mathrm{O}_{3}$ is initiated by $\mathrm{K}_{2} \mathrm{CrO}_{4}$ formation as found in the corrosion literature. ${ }^{22,23,43}$ However, we argue that the suggested overall reaction of $\mathrm{KCl}$ with $\mathrm{Cr}_{2} \mathrm{O}_{3}$ :

$$
\begin{aligned}
& 4 \mathrm{KCl}+\mathrm{Cr}_{2} \mathrm{O}_{3}+1 \frac{1}{2} \mathrm{O}_{2}(\mathrm{~g})+2 \mathrm{H}_{2} \mathrm{O}(\mathrm{g}) \rightarrow 2 \mathrm{~K}_{2} \mathrm{CrO}_{4} \\
& +4 \mathrm{HCl}(\mathrm{g})
\end{aligned}
$$

starts with the initiation step:

$$
\mathrm{KCl}+\mathrm{H}_{2} \mathrm{O}(\mathrm{g}) \leftrightarrow \mathrm{KOH}+\mathrm{HCl}(\mathrm{g})
$$

and then the formed $\mathrm{KOH}$ can easily react with the protective oxide as shown in the experiments. Previous hypotheses of the mechanisms of steel corrosion under $\mathrm{KCl}(\mathrm{s})$ exposures have focused on the effect of $\mathrm{Cl}_{2}(\mathrm{~g})$ or $\mathrm{HCl}(\mathrm{g})$ as the corrosive substances and the effect of $\mathrm{KOH}$ has been neglected. ${ }^{\mathbf{4 4 , 4 5}}$ However, combustion environments contain inevitably also $\mathrm{H}_{2} \mathrm{O}(\mathrm{g})$ in the flue gases and therefore $\mathrm{KOH}$ formation should not be neglected. Furthermore, many virgin biomass fuels contain very little $\mathrm{Cl}$, so there is simply not much $\mathrm{Cl}_{2}(\mathrm{~g})$ or $\mathrm{HCl}(\mathrm{g})$ available in the flue gases when combusting these types of fuels. Still KCl layer has been found on the heat exchanger surfaces and previous work has argued that the corroding $\mathrm{Cl}_{2}(\mathrm{~g})$ or $\mathrm{HCl}(\mathrm{g})$ must form from the $\mathrm{KCl}$ layer, but the fate of the $\mathrm{K}$ when the $\mathrm{Cl}_{2}(\mathrm{~g})$ or $\mathrm{HCl}(\mathrm{g})$ forms from $\mathrm{KCl}$ has not been studied in detail. In waste incineration, the situation is different, because the feedstock contains typically large amounts of $\mathrm{Cl}$ and therefore the direct gas phase attack by $\mathrm{Cl}_{2}(\mathrm{~g})$ or $\mathrm{HCl}(\mathrm{g})$ may be more relevant. It may be that the chlorine corrosion 


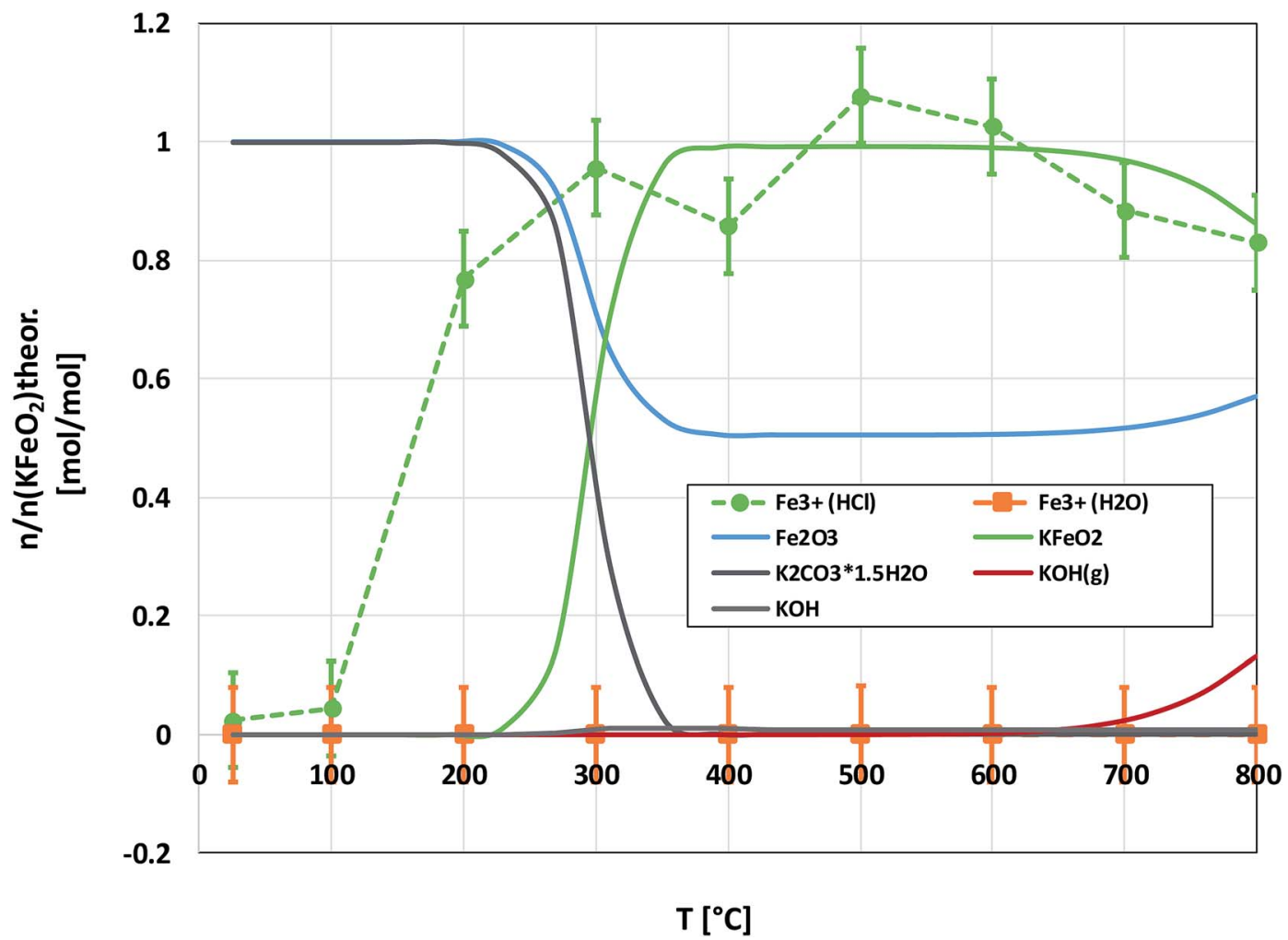

Fig. 7 Comparison of the experimentally determined amount of $\left[\mathrm{Fe}^{3+}\right]$ in the filtrates with the thermodynamically predicted amount of the reaction products in the $\mathrm{KOH}-\mathrm{Fe}_{2} \mathrm{O}_{3}$ system with pure water leaching and leaching in $1 \mathrm{M} \mathrm{HCl}_{(\text {aq) }}$ solution.

mechanisms taking place in high chlorine content feedstock combustion cannot be applied to explain the corrosion in virgin biomass combustion.

\subsection{Reaction of $\mathrm{KOH}$ with $\mathrm{Cr}_{2} \mathrm{O}_{3}$}

$\mathrm{KOH}$ will react readily with $\mathrm{Cr}_{2} \mathrm{O}_{3}$, reacting already at $200{ }^{\circ} \mathrm{C}$ :

$$
\begin{aligned}
4 \mathrm{KOH} & +\mathrm{Cr}_{2} \mathrm{O}_{3}+1 \frac{1}{2} \mathrm{O}_{2}(\mathrm{~g}) \rightarrow 2 \mathrm{~K}_{2} \mathrm{CrO}_{4} \\
& +2 \mathrm{H}_{2} \mathrm{O}(\mathrm{g}) \quad\left(T \geq 20{ }^{\circ} \mathrm{C}\right)
\end{aligned}
$$

The formed $\mathrm{K}_{2} \mathrm{CrO}_{4}$ can react further to $\mathrm{K}_{2} \mathrm{Cr}_{2} \mathrm{O}_{7}$ at high temperatures. Direct formation of $\mathrm{K}_{2} \mathrm{Cr}_{2} \mathrm{O}_{7}$ without the $\mathrm{K}_{2} \mathrm{CrO}_{4}$ intermediate is always kinetically hindered:

$$
2 \mathrm{~K}_{2} \mathrm{CrO}_{4}+\mathrm{Cr}_{2} \mathrm{O}_{3}+1 \frac{1}{2} \mathrm{O}_{2}(\mathrm{~g}) \leftrightarrow 2 \mathrm{~K}_{2} \mathrm{Cr}_{2} \mathrm{O}_{7} \quad\left(T>400{ }^{\circ} \mathrm{C}\right)
$$

\subsection{Reaction of $\mathrm{KOH}$ with $\mathrm{Fe}_{2} \mathrm{O}_{3}$}

$\mathrm{KOH}$ will react readily with $\mathrm{Fe}_{2} \mathrm{O}_{3}$, reacting already at $200{ }^{\circ} \mathrm{C}$ :

$$
2 \mathrm{KOH}+\mathrm{Fe}_{2} \mathrm{O}_{3} \rightarrow 2 \mathrm{KFeO}_{2}+\mathrm{H}_{2} \mathrm{O}(\mathrm{g})\left(T \geq 200{ }^{\circ} \mathrm{C}\right)
$$

Although not experimentally verified in this study, we propose that in analogy to $\mathrm{KOH}-\mathrm{Cr}_{2} \mathrm{O}_{3}$ case, the formed $\mathrm{KFeO}_{2}$ can react further to $\mathrm{K}_{2} \mathrm{Fe}_{4} \mathrm{O}_{7}$ at high temperatures. It is suggested that $\mathrm{K}_{2} \mathrm{Fe}_{4} \mathrm{O}_{7}$ formation without the $\mathrm{KFeO}_{2}$ intermediate is kinetically hindered as the $\mathrm{K}_{2} \mathrm{Cr}_{2} \mathrm{O}_{7}$ formation in the $\mathrm{Cr}_{2} \mathrm{O}_{3}$ case:

$$
2 \mathrm{KFeO}_{2}+\mathrm{Fe}_{2} \mathrm{O}_{3} \leftrightarrow \mathrm{K}_{2} \mathrm{Fe}_{4} \mathrm{O}_{7}\left(T>700{ }^{\circ} \mathrm{C}\right)
$$

\subsection{Reaction of $\mathrm{KCl}$ with $\mathrm{Cr}_{2} \mathrm{O}_{3}$ and $\mathrm{Fe}_{2} \mathrm{O}_{3}$}

Based on the results in this study, it is proposed that the reactivity of $\mathrm{KCl}$ towards both oxides in $\mathrm{H}_{2} \mathrm{O}(\mathrm{g})$ containing environment can simply be explained by the thermodynamics of the decomposition reaction R2. Fig. 10 presents the thermodynamic equilibrium of $\mathrm{R} 2$ in ambient moist air. It is suggested that $\mathrm{HCl}(\mathrm{g})$ does not play a key role in the reaction with the oxides and that the reactive compound is the formed $\mathrm{KOH}$. The reason that we did not detect any reaction between $\mathrm{KCl}$ and $\mathrm{Fe}_{2} \mathrm{O}_{3}$, but did detect $\mathrm{K}_{2} \mathrm{CrO}_{4}$ formation with $\mathrm{Cr}_{2} \mathrm{O}_{3}$ at $>500{ }^{\circ} \mathrm{C}$ can be explained by the higher thermodynamic stability of $\mathrm{K}_{2} \mathrm{CrO}_{4}$ compared to $\mathrm{KFeO}_{2}$ as shown in Fig. $11 . \mathrm{K}_{2} \mathrm{CrO}_{4}$ is much more stable than $\mathrm{KFeO}_{2}$, therefore it is suggested that the $\mathrm{KOH}$ formed in the decomposition of $\mathrm{KCl}$ at $>500{ }^{\circ} \mathrm{C}$ does not form $\mathrm{KFeO}_{2}$ as readily as $\mathrm{K}_{2} \mathrm{CrO}_{4}$ and most of the formed $\mathrm{KOH}$ is lost in the gas phase by vaporization before reacting with $\mathrm{Fe}_{2} \mathrm{O}_{3}$. That is why $\mathrm{KFeO}_{2}$ was not detected in the $\mathrm{KCl}-\mathrm{Fe}_{2} \mathrm{O}_{3}$ system.

In case of $\mathrm{Fe}-\mathrm{Cr}$ steel corrosion, once the protective oxide is destroyed by $\mathrm{KOH}$ and if the bare metals are exposed to the 


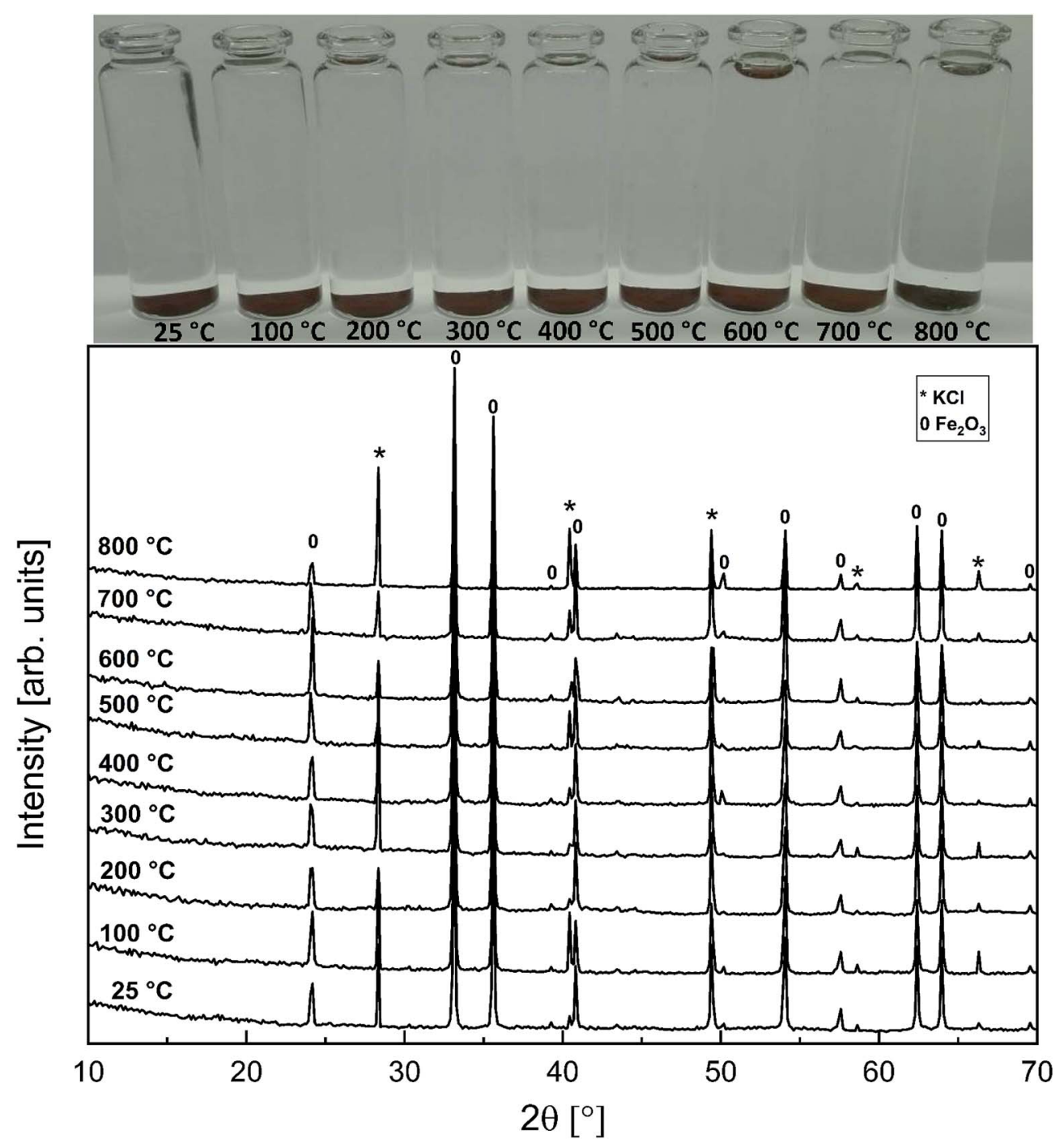

Fig. 8 XRD patterns and appearance of the water solutions on top of the $\mathrm{KCl}-\mathrm{Fe}_{2} \mathrm{O}_{3}$ mixtures after furnace exposures.

atmosphere, $\mathrm{HCl}(\mathrm{g})$ may take part in the continuation of corrosion:

$$
\begin{gathered}
\mathrm{Cr}+2 \mathrm{HCl}(\mathrm{g})+\frac{1}{2} \mathrm{O}_{2}(\mathrm{~g}) \rightarrow \mathrm{CrCl}_{2}(\mathrm{~g})+\mathrm{H}_{2} \mathrm{O}(\mathrm{g}) \\
\mathrm{Fe}+2 \mathrm{HCl}(\mathrm{g})+\frac{1}{2} \mathrm{O}_{2}(\mathrm{~g}) \rightarrow \mathrm{FeCl}_{2}(\mathrm{~g})+\mathrm{H}_{2} \mathrm{O}(\mathrm{g}) \\
\mathrm{Cr}+3 \mathrm{HCl}(\mathrm{g})+\frac{3}{4} \mathrm{O}_{2}(\mathrm{~g}) \rightarrow \mathrm{CrCl}_{3}(\mathrm{~g})+1 \frac{1}{2} \mathrm{H}_{2} \mathrm{O}(\mathrm{g}) \\
\mathrm{Fe}+3 \mathrm{HCl}(\mathrm{g})+\frac{3}{4} \mathrm{O}_{2}(\mathrm{~g}) \rightarrow \mathrm{FeCl}_{3}(\mathrm{~g})+1 \frac{1}{2} \mathrm{H}_{2} \mathrm{O}(\mathrm{g})
\end{gathered}
$$

If $\mathrm{KCl}$ diffuses through the oxide scale (grain boundary diffusion), the formation of the reactive chlorine species can also take place at the metal-scale interface:

$$
\mathrm{Cr}+2 \mathrm{KCl}+2 \mathrm{O}_{2}(\mathrm{~g}) \rightarrow \mathrm{K}_{2} \mathrm{CrO}_{4}+\mathrm{Cl}_{2}(\mathrm{~g})
$$

$$
\begin{gathered}
\mathrm{Cr}+2 \mathrm{KCl}+4 \mathrm{H}_{2} \mathrm{O}(\mathrm{g}) \rightarrow \mathrm{K}_{2} \mathrm{CrO}_{4}+2 \mathrm{HCl}(\mathrm{g})+\mathrm{H}_{2}(\mathrm{~g}) \\
2 \mathrm{Fe}+2 \mathrm{KCl}+2 \mathrm{O}_{2}(\mathrm{~g}) \rightarrow 2 \mathrm{KFeO}_{2}+\mathrm{Cl}_{2}(\mathrm{~g})
\end{gathered}
$$

$$
2 \mathrm{Fe}+2 \mathrm{KCl}+2 \mathrm{H}_{2} \mathrm{O}(\mathrm{g}) \rightarrow 2 \mathrm{KFeO}_{2}+2 \mathrm{HCl}(\mathrm{g})+\mathrm{H}_{2}(\mathrm{~g})
$$

The formed chlorine compounds can further attack the metal leading to the active oxidation mechanism by chlorine. ${ }^{46}$ However, it is somewhat arbitrary to speculate about the corrosion reactions with elemental metals, because these reactive metals in the elemental form will thermodynamically favour reaction with practically any reactant. For example, a chlorine free corrosion mechanism involving only $\mathrm{KOH}$ may also be suggested:

$$
\begin{aligned}
& \mathrm{Cr}+2 \mathrm{KOH}+1 \frac{1}{2} \mathrm{O}_{2}(\mathrm{~g}) \rightarrow \mathrm{K}_{2} \mathrm{CrO}_{4}+\mathrm{H}_{2} \mathrm{O}(\mathrm{g}) \\
& 2 \mathrm{Fe}+2 \mathrm{KOH}+1 \frac{1}{2} \mathrm{O}_{2}(\mathrm{~g}) \rightarrow 2 \mathrm{KFeO}_{2}+\mathrm{H}_{2} \mathrm{O}(\mathrm{g})
\end{aligned}
$$




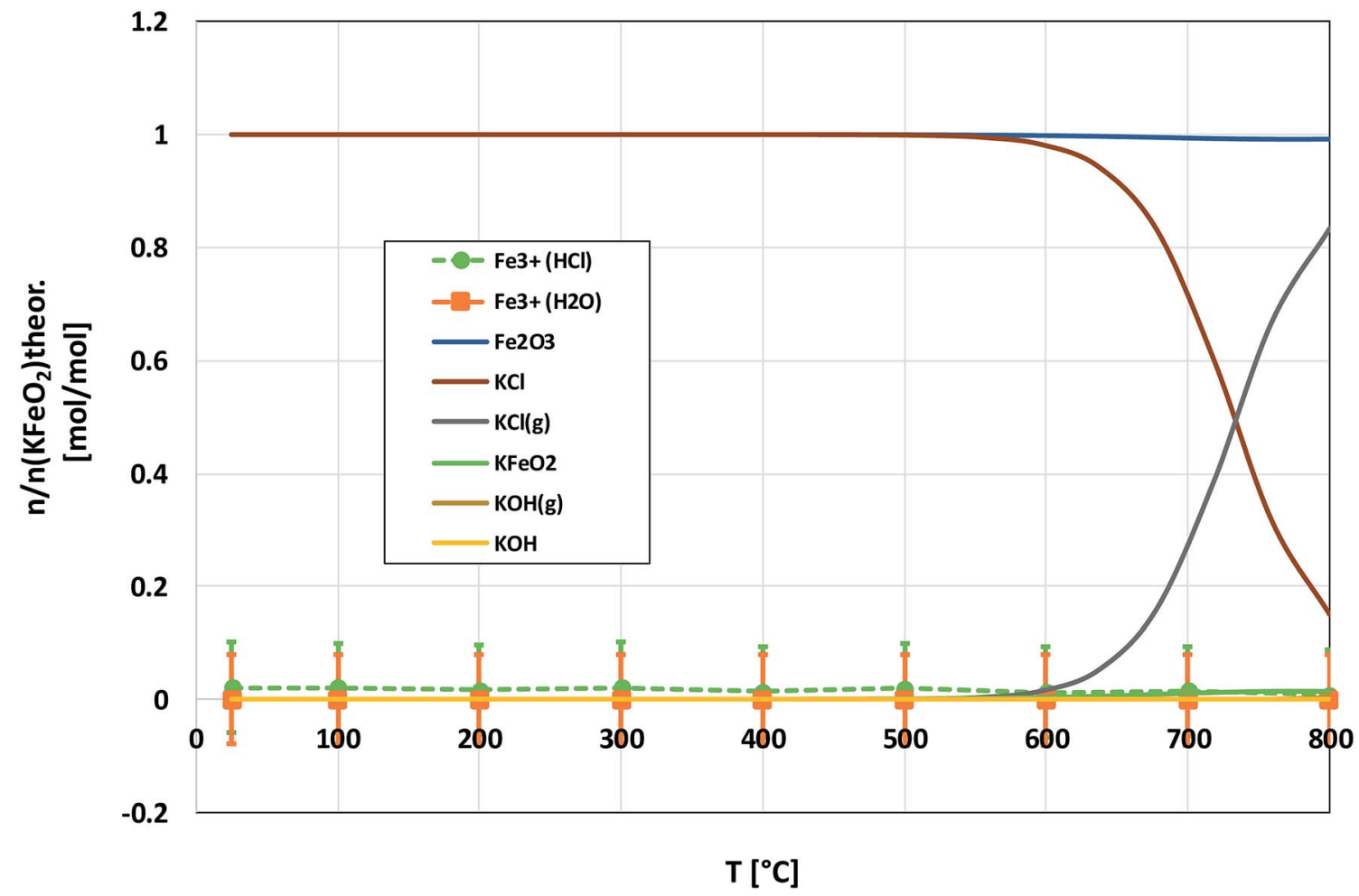

Fig. 9 Comparison of the experimentally determined amount of $\left[\mathrm{Fe}^{3+}\right]$ in the filtrates with the thermodynamically predicted amount of the reaction products in the $\mathrm{KCl}-\mathrm{Fe}_{2} \mathrm{O}_{3}$ system with pure water leaching and leaching in $1 \mathrm{M} \mathrm{HCl}_{(\mathrm{aq})}$ solution.

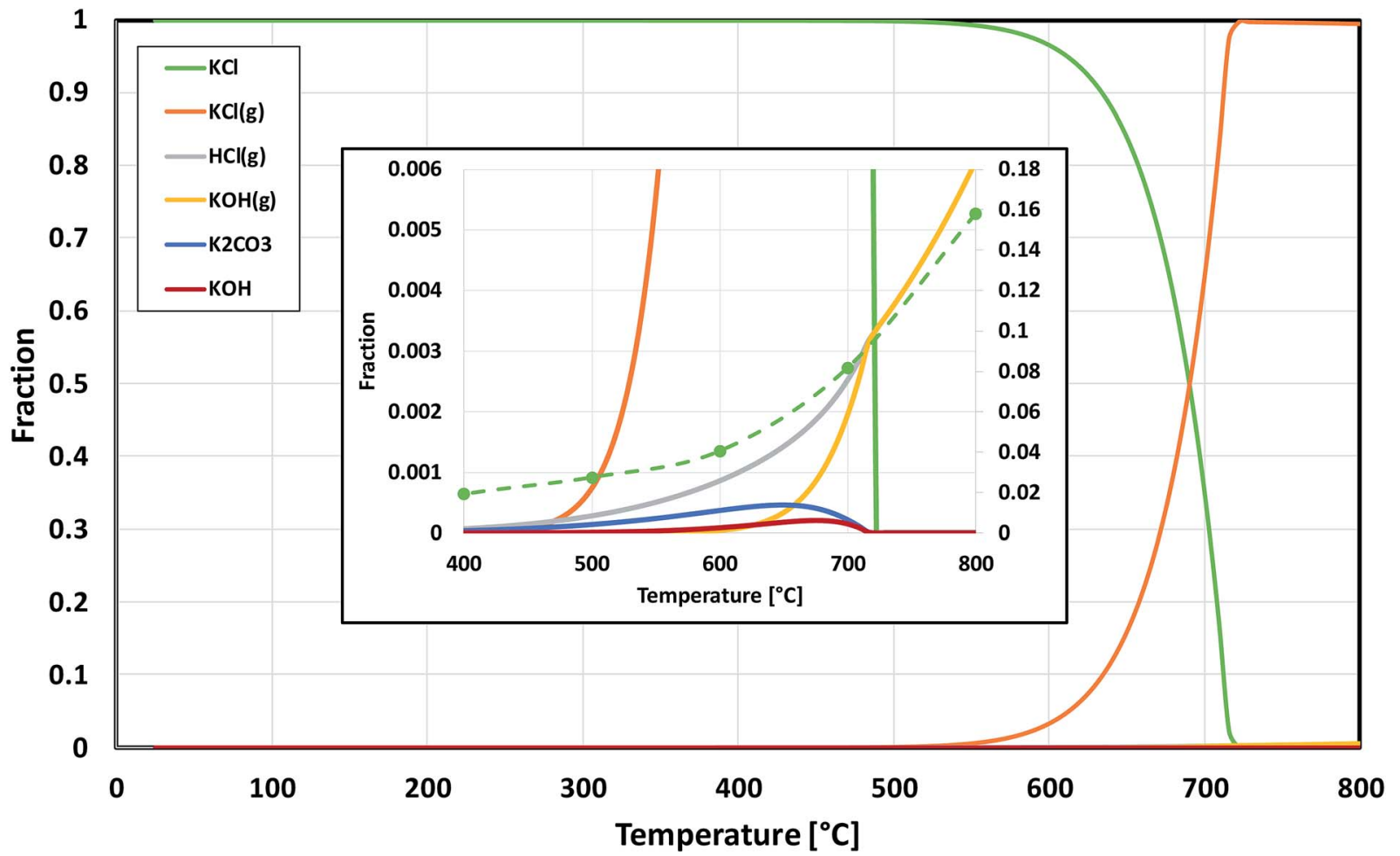

Fig. 10 Thermodynamic stability of $\mathrm{KCl}$ in humid air, calculated with $\mathrm{HSC}$ v6.12 software. The inset is a zoomed image from the bottom right corner of the chart. The green dashed line in the inset shows the trend of the experimentally determined amount of potassium reacted to $\mathrm{K}_{2} \mathrm{CrO}_{4}$ when $\mathrm{KCl}$ and $\mathrm{Cr}_{2} \mathrm{O}_{3}$ reacted in the furnace (shown also in Fig. 5). 


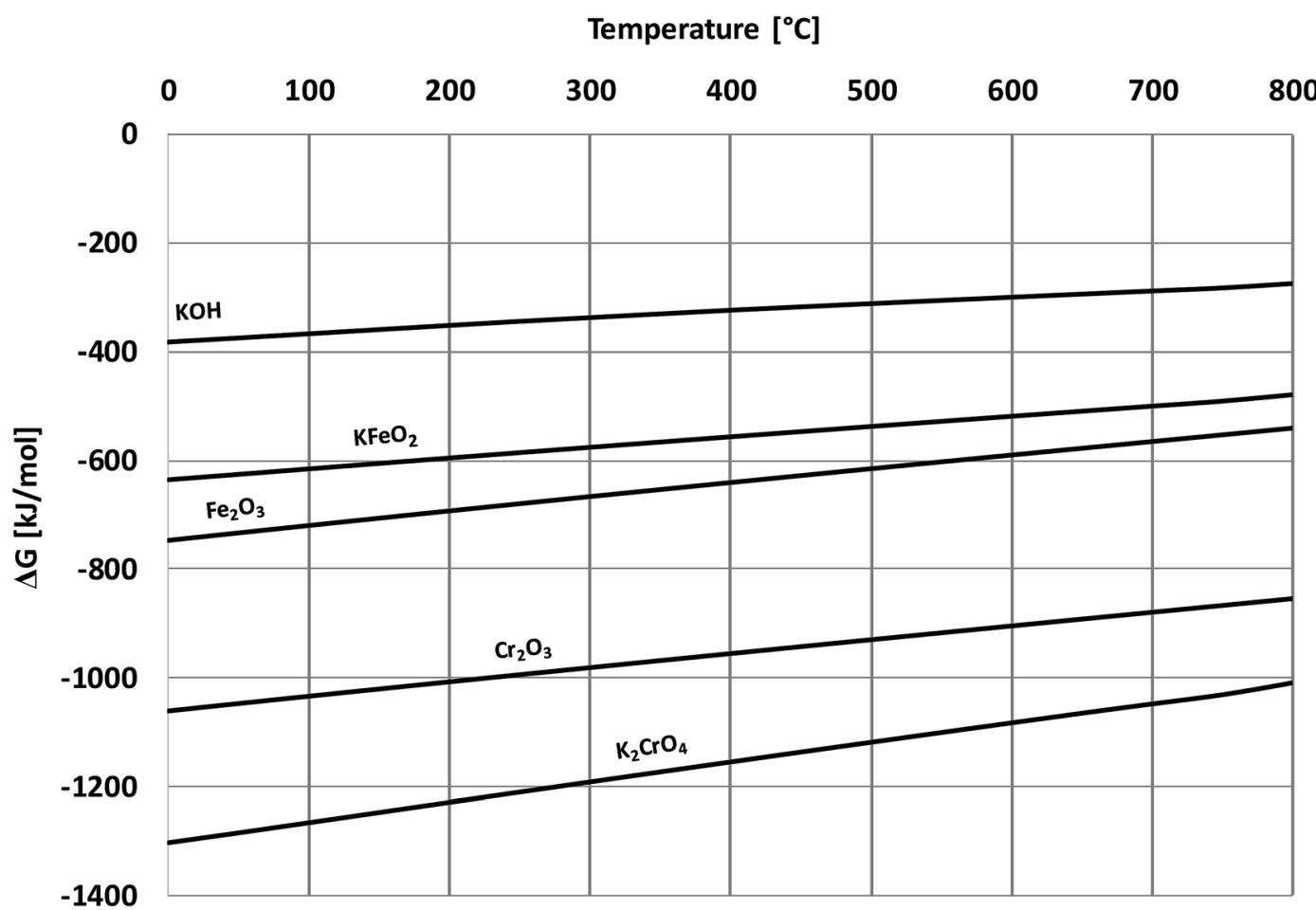

Fig. 11 Comparison of Gibbs free energies of formation of the reactants and the corrosion products, calculated with HSC v6.12 software.

The formed water or the $\mathrm{O}_{2}(\mathrm{~g})$ diffusing through the oxide scale can further oxidize the underlying metal and form $\mathrm{Cr}_{2} \mathrm{O}_{3}$ or $\mathrm{Fe}_{2} \mathrm{O}_{3}$ oxides, which are then consumed by $\mathrm{KOH}$ according to reactions $\mathrm{R} 3$ and $\mathrm{R} 5$, and a chlorine free active oxidation mechanism is established. It is argued that $\mathrm{KOH}$ diffuses more readily to the metal scale interphase than $\mathrm{KCl}$, because of the lower melting point of $\mathrm{KOH}\left(406^{\circ} \mathrm{C}\right)$ compared to $\mathrm{KCl}\left(773^{\circ} \mathrm{C}\right)$ and thus higher mobility at typical service temperatures (400$600{ }^{\circ} \mathrm{C}$ ). Because of the low melting point of $\mathrm{KOH}$, diffusion can also take place in ionic form by $\mathrm{K}^{+}$and $\mathrm{O}^{2-}$ ions diffusing to the metal-scale interphase:

$$
\begin{aligned}
& 2 \mathrm{KOH}\left.\leftrightarrow \mathrm{K}_{2} \mathrm{O}+\mathrm{H}_{2} \mathrm{O}(\mathrm{g}) \text { (in liquid } \mathrm{KOH}\right) \\
& \mathrm{K}_{2} \mathrm{O} \rightarrow 2 \mathrm{~K}^{+}+\mathrm{O}^{2-} \text { (in liquid } \mathrm{KOH} \text { ) } \\
& \mathrm{Cr}+2 \mathrm{~K}^{+}+\mathrm{O}^{2-}+1 \frac{1}{2} \mathrm{O}_{2}(\mathrm{~g}) \rightarrow \mathrm{K}_{2} \mathrm{CrO}_{4}
\end{aligned}
$$$$
\text { (at metal-scale interface) }
$$

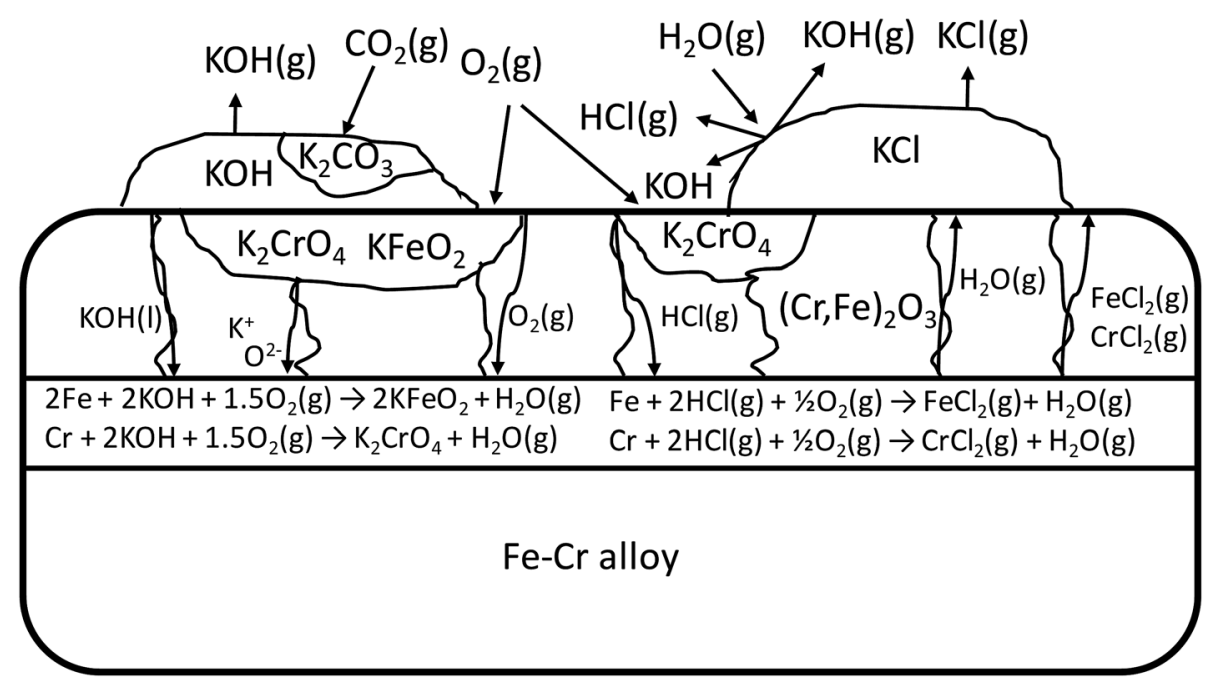

Fig. 12 Schematic of the proposed corrosion reactions under $\mathrm{KOH}$ and $\mathrm{KCl}$ containing salt deposit. 


$$
2 \mathrm{Fe}+2 \mathrm{~K}^{+}+\mathrm{O}^{2-}+1 \frac{1}{2} \mathrm{O}_{2}(\mathrm{~g}) \rightarrow 2 \mathrm{KFeO}_{2}
$$

(at metal-scale interface)

The schematic image in Fig. 12 summarizes the proposed corrosion reactions.

\section{Conclusions}

$\mathrm{KOH}$ is much more reactive towards $\mathrm{Cr}_{2} \mathrm{O}_{3}$ and $\mathrm{Fe}_{2} \mathrm{O}_{3}$ than $\mathrm{KCl}$ in ambient air environment. Thermodynamic calculations predict the difference in reactivity quite nicely above $400{ }^{\circ} \mathrm{C}$. $\mathrm{KOH}$ reacts with both oxides at temperatures higher than $200{ }^{\circ} \mathrm{C}$ while $\mathrm{KCl}$ reacts with $\mathrm{Cr}_{2} \mathrm{O}_{3}$ at temperatures $>400{ }^{\circ} \mathrm{C}$, but no reaction with $\mathrm{Fe}_{2} \mathrm{O}_{3}$ was detected in the temperature range from room temperature to $800{ }^{\circ} \mathrm{C}$. Both $\mathrm{KOH}$ and $\mathrm{KCl}$ form $\mathrm{K}_{2} \mathrm{CrO}_{4}$ as the reaction product when reacting with $\mathrm{Cr}_{2} \mathrm{O}_{3} \cdot \mathrm{K}_{2} \mathrm{CrO}_{4}$ can further react with $\mathrm{Cr}_{2} \mathrm{O}_{3}$ and form $\mathrm{K}_{2} \mathrm{Cr}_{2} \mathrm{O}_{7}$ at temperatures > $400{ }^{\circ} \mathrm{C}$. $\mathrm{K}_{2} \mathrm{CrO}_{4}$ and $\mathrm{K}_{2} \mathrm{Cr}_{2} \mathrm{O}_{7}$ reaction products can be easily leached from the mixture with water at room temperature. $\mathrm{KOH}$ forms $\mathrm{KFeO}_{2}$ as the reaction product when reacting with $\mathrm{Fe}_{2} \mathrm{O}_{3}$. $\mathrm{KFeO}_{2}$ cannot be leached with pure water, but requires an acidic media. In $1 \mathrm{M} \mathrm{HCl}$ solution, $\mathrm{KFeO}_{2}$ can be easily leached at room temperature. The reactivity of $\mathrm{KCl}$ towards the protective oxides of $\mathrm{Fe}-\mathrm{Cr}$ steels in water containing high temperature environments can be explained by its decomposition to $\mathrm{KOH}$ and $\mathrm{HCl}(\mathrm{g})$ and the subsequent reaction of the formed $\mathrm{KOH}$ with the protective oxide. These results are very valuable for the development of materials for boilers, gasifiers, furnaces and gas turbines utilizing biomass derived fuels as their energy source.

\section{Conflicts of interest}

There are no conflicts of interest to declare.

\section{Acknowledgements}

The financial support from the Academy of Finland Strategic Research Council (SRC) and Finnish Environment Institute (SYKE) through the CloseLoop project is gratefully appreciated.

\section{References}

1 IEA statistics, $\mathrm{CO}_{2}$ Emissions from Fuel Combustion 2017 Highlights, 1 October 2017.

2 Y. Niu, H. Tan and S. Hui, Ash-related issues during biomass combustion: alkali-induced slagging, silicate melt-induced slagging (ash fusion), agglomeration, corrosion, ash utilization, and related countermeasures, Prog. Energy Combust. Sci., 2016, 52, 1-61.

3 H. P. Nielsen, F. J. Frandsen, K. Dam-Johansena and L. L. Baxter, The implications of chlorine-associated corrosion on the operation of biomass-fired boilers, Prog. Energy Combust. Sci., 2000, 26, 283-298.

4 R. A. Antunes and M. C. L. Oliveira, Corrosion in biomass combustion: a materials selection analysis and its interaction with corrosion mechanisms and mitigation strategies, Corros. Sci., 2013, 76, 6-26.

5 I. Obernberger, F. Biedermann, W. Widmann and R. Riedl, Concentrations of inorganic elements in biomass fuels and recovery in the different ash fractions, Biomass Bioenergy, 1997, 12, 211-224.

6 L. L. Baxtera, T. R. Miles, T. R. Miles Jr, B. M. Jenkins, T. Milne, D. Dayton, R. W. Bryerse and L. L. Oden, The behavior of inorganic material in biomass-fired power boilers: field and laboratory experiences, Fuel Process. Technol., 1998, 54, 47-78.

7 C. Chen, Z. Luo, C. Yu, T. Wang and H. Zhang, Transformation behavior of potassium during pyrolysis of biomass, RSC Adv., 2017, 7, 31319-31325.

8 D. C. Dayton, R. J. French and T. A. Milne, Direct Observation of Alkali Vapor Release during Biomass Combustion and Gasification. 1. Application of Molecular Beam/Mass Spectrometry to Switchgrass Combustion, Energy Fuels, 1995, 9, 855-865.

9 T. Sorvajärvi, N. DeMartini, J. Rossi and J. Toivonen, In Situ Measurement Technique for Simultaneous Detection of $\mathrm{K}$, $\mathrm{KCl}$, and $\mathrm{KOH}$ Vapors Released during Combustion of Solid Biomass Fuel in a Single Particle Reactor, Appl. Spectrosc., 2014, 68, 179-184.

10 P. E. Mason, L. I. Darvell, J. M. Jones and A. Williams, Observations on the release of gas-phase potassium during the combustion of single particles of biomass, Fuel, 2016, 182, 110-117.

11 Y. Niu, Z. Wang, Y. Zhu, X. Zhang, H. Tan and S. Hui, Experimental evaluation of additives and $\mathrm{K}_{2} \mathrm{O}-\mathrm{SiO}_{2}-\mathrm{Al}_{2} \mathrm{O}_{3}$ diagrams on high-temperature silicate melt-induced slagging during biomass combustion, Fuel, 2016, 179, 52-59.

12 B. Anicic, W. Lin, K. Dam-Johansen and $\mathrm{H}$. Wu, Agglomeration mechanism in biomass fluidized bed combustion - reaction between potassium carbonate and silica sand, Fuel Process. Technol., 2018, 173, 182-190.

13 M. Hupa, Ash-Related Issues in Fluidized-Bed Combustion of Biomasses: Recent Research Highlights, Energy Fuels, 2012, 26, 4-14.

14 L. Hindiyarti, F. Frandsen, H. Livbjerg, P. Glarborg and P. Marshall, An exploratory study of alkali sulfate aerosol formation during biomass combustion, Fuel, 2008, 87, 1591-1600.

15 S. Jiménez and J. Ballester, Formation and Emission of Submicron Particles in Pulverized Olive Residue (Orujillo) Combustion, Aerosol Sci. Technol., 2004, 38, 707-723.

16 L. A. Hansen, H. P. Nielsen, F. J. Frandsen, K. DamJohansen, S. Hørlyck and A. Karlsson, Influence of deposit formation on corrosion at a straw-fired boiler, Fuel Process. Technol., 2000, 64, 189-209.

17 H. Wu, M. S. Bashir, P. A. Jensen, B. Sander and P. Glarborg, Impact of coal fly ash addition on ash transformation and deposition in a full-scale wood suspension-firing boiler, Fuel, 2013, 113, 632-643.

18 W. Weng, S. Chen, H. Wu, P. Glarborg and Z. Li, Optical Investigation of Gas-phase $\mathrm{KCl} / \mathrm{KOH}$ Sulfation in Post Flame Conditions, Fuel, 2018, 224, 461-468. 
19 B. Li, Z. Sun, Z. Li, M. Aldén, J. G. Jakobsen, S. Hansen and P. Glarborg, Post-flame gas-phase sulfation of potassium chloride, Combust. Flame, 2013, 160, 959-969.

$20 \mathrm{~K}$. Schofield, The chemical nature of combustion deposition and corrosion: the case of alkali chlorides, Combust. Flame, 2012, 159, 1987-1996.

21 M. Broström, S. Enestam, R. Backman and K. Mäkelä, Condensation in the $\mathrm{KCl}-\mathrm{NaCl}$ system, Fuel Process. Technol., 2013, 105, 142-148.

22 S. Karlsson, J. Pettersson, L.-G. Johansson and J.-E. Svensson, Alkali Induced High Temperature Corrosion of Stainless Steel: The Influence of $\mathrm{NaCl}, \mathrm{KCl}$ and $\mathrm{CaCl}_{2}$, Oxid. Met., 2012, 78, 83-102.

23 J. Pettersson, H. Asteman, J.-E. Svensson and L.-G. Johansson, KCl Induced Corrosion of a 304-type Austenitic Stainless Steel at $600^{\circ} \mathrm{C}$; The Role of Potassium, Oxid. Met., 2005, 64, 23-41.

24 Y. S. Lia, M. Spiegel and S. Shimada, Effect of Al/Si addition on $\mathrm{KCl}$ induced corrosion of 9\% Cr steel, Mater. Lett., 2004, 58, 3787-3791.

25 H. T. Ma, C. H. Zhou and L. Wang, High temperature corrosion of pure $\mathrm{Fe}, \mathrm{Cr}$ and $\mathrm{Fe}-\mathrm{Cr}$ binary alloys in $\mathrm{O}_{2}$ containing trace $\mathrm{KCl}$ vapour at $750{ }^{\circ} \mathrm{C}$, Corros. Sci., 2009, 51, 1861-1867.

26 S. Kiamehr, K. V. Dahl, M. Montgomery and M. A. J. Somers, KCl-induced high temperature corrosion of selected commercial alloys, Mater. Corros., 2015, 66, 1414-1429.

27 T. Ishitsuka and K. Nose, Solubility study on protective oxide films in molten chlorides created by refuse incineration environment, Mater. Corros., 2000, 51, 177-181.

28 K. Segerdahl, J. Pettersson, J. E. Svensson and L. G. Johansson, Is $\mathrm{KCl}(\mathrm{g})$ Corrosive at Temperatures Above its Dew Point? Influence of $\mathrm{KCl}(\mathrm{g})$ on Initial Stages of the High Temperature Corrosion of $11 \% \mathrm{Cr}$ Steel at $600^{\circ} \mathrm{C}$, Mater. Sci. Forum, 2004, 461-464, 109-116.

29 J. Lehmusto, D. Lindberg, P. Yrjas, B.-J. Skrifvars and M. Hupa, Thermogravimetric studies of high temperature reactions between potassium salts and chromium, Corros. Sci., 2012, 59, 55-62.

$30 \mathrm{~J}$. Pettersson, N. Folkeson, L.-G. Johansson and J.-E. Svensson, The Effects of $\mathrm{KCl}, \mathrm{K}_{2} \mathrm{SO}_{4}$ and $\mathrm{K}_{2} \mathrm{CO}_{3}$ on the High Temperature Corrosion of a 304-Type Austenitic Stainless Steel, Oxid. Met., 2011, 76, 93-109.

31 G. Y. Lai, High-Temperature Corrosion and Materials Applications, ASM International, Ohio, 2007.

32 G. P. Smith, Corrosion of materials in fused hydroxides, Oak Ridge National Laboratory Report, Tennessee, 1956.

33 Tz. Tzvetkoff and J. Kolchakov, Mechanism of growth, composition and structure of oxide films formed on ferrous alloys in molten salt electrolytes-a review, Mater. Chem. Phys., 2004, 87, 201-211.
34 T. Blomberg, A thermodynamic study of the gaseous potassium chemistry in the convection sections of biomass fired boilers, Mater. Corros., 2011, 57, 170-175.

35 T. Blomberg, Correlation of the corrosion rates of steels in a straw fired boiler with the thermodynamically predicted trend of $\mathrm{KOH}(\mathrm{g})$ in the flue gases, Biomass Bioenergy, 2012, 39, 489-493.

36 S. Parirenyatwa, L. Escudero-Castejon, S. Sanchez-Segado, Y. Hara and A. Jha, Comparative study of alkali roasting and leaching of chromite ores and titaniferous minerals, Hydrometallurgy, 2016, 165, 213-226.

37 N. Li, E. Vainio, L. Hupa, M. Hupa and E. C. Zabetta, HighTemperature Corrosion of Refractory Materials in Biomass and Waste Combustion: Method Development and Tests with Alumina Refractory Exposed to a $\mathrm{K}_{2} \mathrm{CO}_{3}-\mathrm{KCl}$ Mixture, Energy Fuels, 2017, 31, 10046-10054.

38 Z. Zhou, Y. Bo, Y. Zhang, Z. Huang, L. Chen, L. Ge, J. Zhou and $\mathrm{K}$. Cen, Interactions of high-chromia refractory materials with infiltrating coal slag in the oxidizing atmosphere of a cyclone furnace, Ceram. Int., 2014, 40, 3829-3839.

39 M. Szabó, J. Kalmár, T. Ditrói, G. Bellér, G. Lente, N. Simic and I. Fábián, Equilibria and kinetics of chromium(VI) speciation in aqueous solution - a comprehensive study from pH 2 to 11, Inorg. Chim. Acta, 2018, 472, 295-301.

40 C. C. A. Loures, M. A. K. Alcântara, H. J. I. Filho, A. C. S. C. Teixeira, F. T. Silva, T. C. B. Paiva and G. R. L. Samanamud, Advanced Oxidative Degradation Processes: Fundamentals and Applications, Int. Rev. Chem. Eng., 2013, 5, 102-120.

41 A. Roine, et al., Outokumpu HSC Chemistry for Windows, Chemical Reaction and Equilibrium Software 6.12, 2007.

42 F. T. Mackenzie and J. A. Mackenzie, Our changing planet, Prentice-Hall, Upper Saddle River, New Jersey, 1995.

43 T. Jonsson, J. Froitzheim, J. Pettersson, J.-E. Svensson, L.-G. Johansson and M. Halvarsson, The Influence of $\mathrm{KCl}$ on the Corrosion of an Austenitic Stainless Steel (304L) in Oxidizing Humid Conditions at $600{ }^{\circ} \mathrm{C}$ : A Microstructural Study, Oxid. Met., 2009, 72, 213-239.

44 M. Spiegel, A. Zahs and H. J. Grabke, Fundamental aspects of chlorine induced corrosion in power plants, Mater. High Temp., 2003, 20, 153-159.

45 M. Montgomery, A. Karlsson and O. H. Larsen, Field test corrosion experiments in Denmark with biomass fuels. Part 1: Straw-firing, Mater. Corros., 2002, 53, 121-131.

46 H. J. Grabke, E. Reese and M. Spiegel, The effects of chlorides, hydrogen chloride, and sulfur dioxide in the oxidation of steels below deposits, Corros. Sci., 1995, 37, 1023-1043. 